Wie wir jetzt wissen, ist es dann gelungen, Verfahren bzw. Einrichtungen zu schaffen, welche es erlauben, wenigstens die metallischen Komponenten mit gutem Erfolg zurückzugewinnen. Es wurde sogar ein lukratives Geschäft.

Ähnliche Probleme gibt es auch bei der Verarbeitung anderer Wirtschaftsgüter. Wir müssen in der Zukunft diese Stoffe so aussuchen, dass sie sich auf möglichst einfache Weise recyclieren lassen. Es wird die Aufgabe der zukünftigen Forschung sein, die Auslese der verwendbaren Materialien in einer Wertanalyse so auszuwählen, dass die technischen Eigenschaften und die Möglichkeit einer einfachen Reststoffentsorgung in die Evaluierung des Gebrauchswertes einfliessen. Wir müssen die Materialien werkstoffgerechter verwenden.

Einfache Massnahmen können sehr erfolgreich sein.

Ein repräsentatives Beispiel dafür ist Polyethylen. Dieser thermoplastische Kunststoff lässt sich wirtschaftlich wieder in Granulat zurückführen und dadurch auf einfache Weise regenerieren.

Schwierigkeiten treten auf, wenn Polyethylen mit Fremdstoffen verunreinigt wird. Unablösbare Papierklebeetiketten verunmöglichen eine erfolgreiche Regranulierung des Materials, weil die SchmelzFilter verstopft werden. Mit einer auf eine einfache Weise ablösbaren Etikette oder einer direkt auf dem Kunststoff aufgedruckten Beschriftung wäre das Problem gelöst.

Wertanalysen der Materialien im Hinblick auf die Wiederverwertung müssen in Zukunft wesentlich an Bedeutung gewinnen.

\section{Control of Metal-Catalyzed Reactions by Organic Ligands: From Corrinoid and Porphinoid Metal Complexes to Tailor-Made Catalysts for Asymmetric Synthesis**}

\author{
Andreas Pfaltz* \\ Dedicated to Prof. Albert Eschenmoser on the occasion of his 65th birthday
}

\begin{abstract}
Corrinoid and porphinoid metal complexes play a fundamental role in nature as catalysts for a variety of biochemical transformations. The properties of the metal ion in these complexes are strongly influenced by the macrocyclic ligand. In this way, the reactivity of the metal complex is adjusted to the specific requirements of enzymatic catalysis. This is illustrated in the first part of this article, which is centered on the structure and properties of coenzyme F 430, a hydroporphinoid nickel complex involved in the methane-producing step of the energy metabolism of methanogenic bacteria. A different group of metal complexes, which exemplify the concept of ligand-based selectivity control, is discussed in the second part, summarizing our work on enantioselective catalysis. Inspired by the structure of corrinoid and hydroporphinoid compounds, we have developed a route to chiral $C_{2}$-symmetric semicorrins, a particular class of bidentate nitrogen ligands specifically designed for the stereocontrol of metal-catalyzed reactions. Semicorrins were found to induce remarkable enantioselectivities in the cobalt-catalyzed conjugate reduction of $\alpha, \beta$-unsaturated carboxylic esters and amides and in the coppercatalyzed cyclopropanation of olefins with diazo compounds.
\end{abstract}

\section{Introduction}

The phenomenal development of organometallic chemistry over the last decades has had an enormous impact on organic synthesis. The organic chemist's repertoire today contains an impressive, steadily growing selection of metal-mediated transformations [1]. By exploiting the diverse reactivity patterns of the various metals, the scope of organic synthesis has been considerably enhanced. New types of

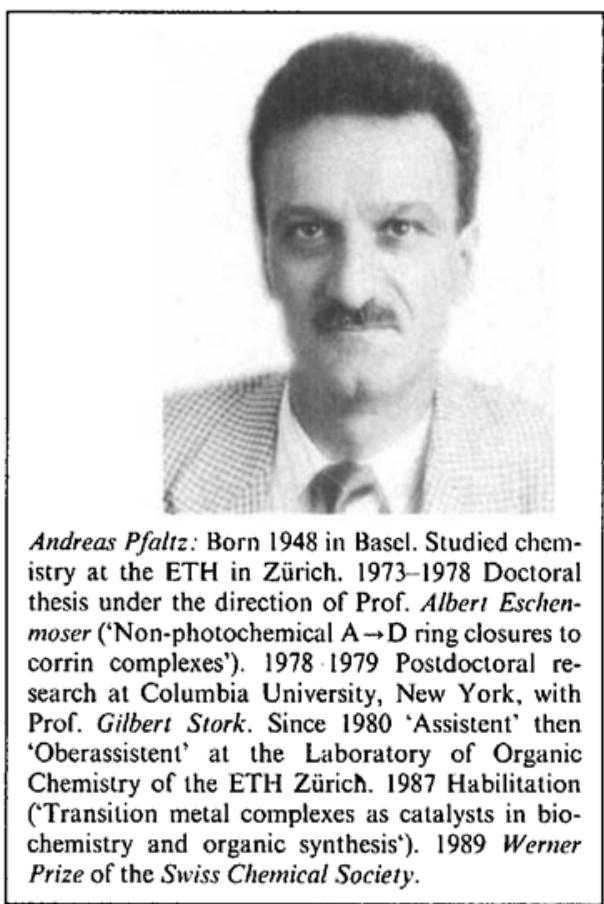

transformations have become possible which often proceed under mild conditions and with unusual selectivity.

However, long before chemists discovered the almost unlimited potential of metal-based reagents and catalysts, metal complexes played a major role in the catalysis of biochemical reactions. Many fundamental processes of life, such as photosynthesis, the respiratory chain, or nitrogen fixation, depend on metals [2] [3a].

\section{* Correspondence: PD Dr. A. Pfaltz Laboratorium für Organische Chemic Eidgenössische Technische Hochschule Zürich ETH-Zentrum \\ CH-8092 Zürich}

** Based on the Werner Prize Lecture 'Von Corrinund Hydrocorphin-Metallkomplexen zu massgeschneiderten Katalysatoren für die asymmetrische Synthese', given at the fall meeting of the Swiss Chemical Society, October 20, 1989 in Bern. 
Wie wir jetzt wissen, ist es dann gelungen, Verfahren bzw. Einrichtungen zu schaffen, welche es erlauben, wenigstens die metallischen Komponenten mit gutem Erfolg zurückzugewinnen. Es wurde sogar ein lukratives Geschäft.

Ähnliche Probleme gibt es auch bei der Verarbeitung anderer Wirtschaftsgüter. Wir müssen in der Zukunft diese Stoffe so aussuchen, dass sie sich auf möglichst einfache Weise recyclieren lassen. Es wird die Aufgabe der zukünftigen Forschung sein, die Auslese der verwendbaren Materialien in einer Wertanalyse so auszuwählen, dass die technischen Eigenschaften und die Möglichkeit einer einfachen Reststoffentsorgung in die Evaluierung des Gebrauchswertes einfliessen. Wir müssen die Materialien werkstoffgerechter verwenden.

Einfache Massnahmen können sehr erfolgreich sein.

Ein repräsentatives Beispiel dafür ist Polyethylen. Dieser thermoplastische Kunststoff lässt sich wirtschaftlich wieder in Granulat zurückführen und dadurch auf einfache Weise regenerieren.

Schwierigkeiten treten auf, wenn Polyethylen mit Fremdstoffen verunreinigt wird. Unablösbare Papierklebeetiketten verunmöglichen eine erfolgreiche Regranulierung des Materials, weil die SchmelzFilter verstopft werden. Mit einer auf eine einfache Weise ablösbaren Etikette oder einer direkt auf dem Kunststoff aufgedruckten Beschriftung wäre das Problem gelöst.

Wertanalysen der Materialien im Hinblick auf die Wiederverwertung müssen in Zukunft wesentlich an Bedeutung gewinnen.

\section{Control of Metal-Catalyzed Reactions by Organic Ligands: From Corrinoid and Porphinoid Metal Complexes to Tailor-Made Catalysts for Asymmetric Synthesis**}

\author{
Andreas Pfaltz* \\ Dedicated to Prof. Albert Eschenmoser on the occasion of his 65th birthday
}

\begin{abstract}
Corrinoid and porphinoid metal complexes play a fundamental role in nature as catalysts for a variety of biochemical transformations. The properties of the metal ion in these complexes are strongly influenced by the macrocyclic ligand. In this way, the reactivity of the metal complex is adjusted to the specific requirements of enzymatic catalysis. This is illustrated in the first part of this article, which is centered on the structure and properties of coenzyme F 430, a hydroporphinoid nickel complex involved in the methane-producing step of the energy metabolism of methanogenic bacteria. A different group of metal complexes, which exemplify the concept of ligand-based selectivity control, is discussed in the second part, summarizing our work on enantioselective catalysis. Inspired by the structure of corrinoid and hydroporphinoid compounds, we have developed a route to chiral $C_{2}$-symmetric semicorrins, a particular class of bidentate nitrogen ligands specifically designed for the stereocontrol of metal-catalyzed reactions. Semicorrins were found to induce remarkable enantioselectivities in the cobalt-catalyzed conjugate reduction of $\alpha, \beta$-unsaturated carboxylic esters and amides and in the coppercatalyzed cyclopropanation of olefins with diazo compounds.
\end{abstract}

\section{Introduction}

The phenomenal development of organometallic chemistry over the last decades has had an enormous impact on organic synthesis. The organic chemist's repertoire today contains an impressive, steadily growing selection of metal-mediated transformations [1]. By exploiting the diverse reactivity patterns of the various metals, the scope of organic synthesis has been considerably enhanced. New types of

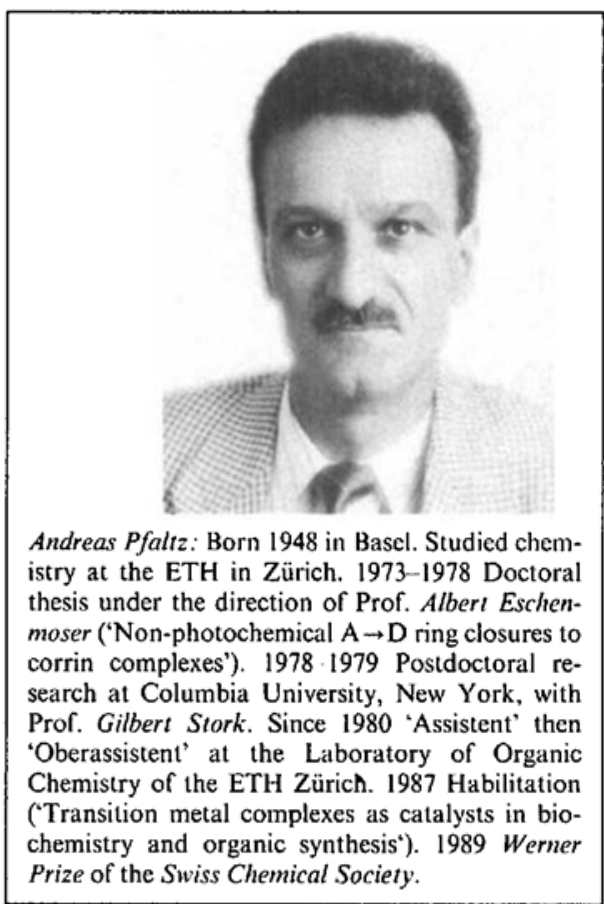

transformations have become possible which often proceed under mild conditions and with unusual selectivity.

However, long before chemists discovered the almost unlimited potential of metal-based reagents and catalysts, metal complexes played a major role in the catalysis of biochemical reactions. Many fundamental processes of life, such as photosynthesis, the respiratory chain, or nitrogen fixation, depend on metals [2] [3a].

\section{* Correspondence: PD Dr. A. Pfaltz Laboratorium für Organische Chemic Eidgenössische Technische Hochschule Zürich ETH-Zentrum \\ CH-8092 Zürich}

** Based on the Werner Prize Lecture 'Von Corrinund Hydrocorphin-Metallkomplexen zu massgeschneiderten Katalysatoren für die asymmetrische Synthese', given at the fall meeting of the Swiss Chemical Society, October 20, 1989 in Bern. 

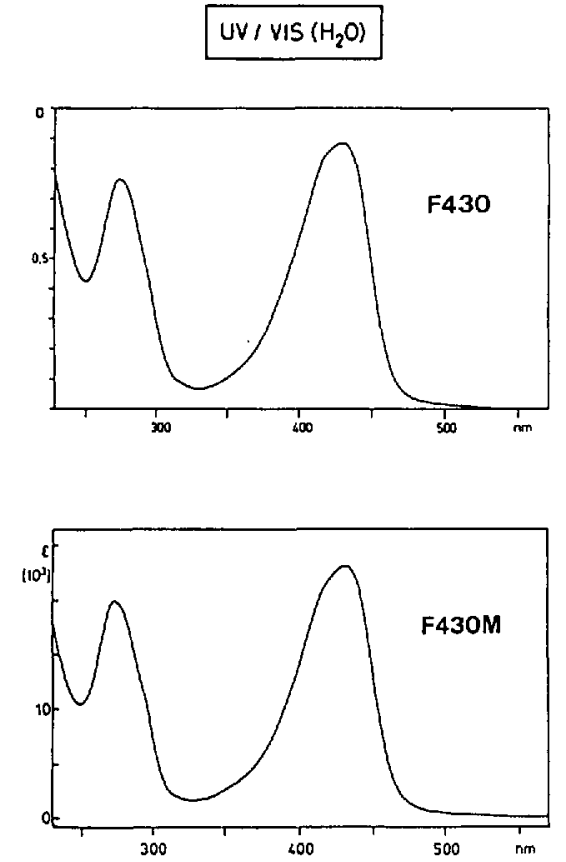

Fig. 1. Isolation and methanolysis of factor F430: UV/VIS spectra of factor F430 and of the methanolysis product F430M
Methanobacterium thermoautotrophicum

$$
\begin{aligned}
& \mathrm{HClO}_{4} / \mathrm{H}_{2} \mathrm{O} \\
& \mathrm{pH} 2 / 4^{\circ} \mathrm{C}
\end{aligned}
$$

F 430

paramagnetic in $\mathrm{H}_{2} \mathrm{O}$, MeOH

$\mathrm{MeOH} / \mathrm{TsOH}$ $40^{\circ} \mathrm{C}$

\section{F 430M}

paramagnetic in $\mathrm{H}_{2} \mathrm{O}$, MeOH diamagnetic in $\mathrm{CH}_{2} \mathrm{Cl}_{2}$ (NMR)
The properties of an organometallic reagent or catalyst do not only depend on the particular metal and its oxidation state. They are also strongly influenced by additional ligands which coordinate to the metal center, but do not participate in the actual metal-mediated process. By means of a properly designed organic ligand, the reactivity and selectivity of a metal complex may be adjusted to the specific requirements of a particular situation. This is demonstrated in a masterly manner by numerous metallo-enzymes and -coenzymes [2]. Distinctive examples are found among the metal porphinoids and corrinoids, a group of macrocyclic metal complexes which play a vital role in many metabolic processes [3]. One particular representative of this class of compounds, which illustrates the importance of the interplay between the metal ion and the organic ligand in complexes of this type, is discussed in the following section.

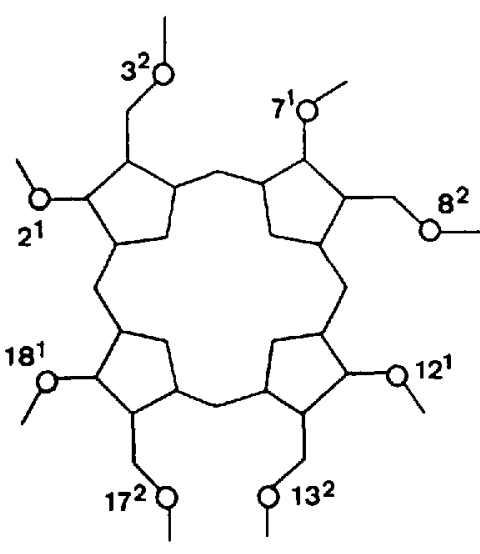

A<smiles>NCC(=O)COC(=O)O</smiles>
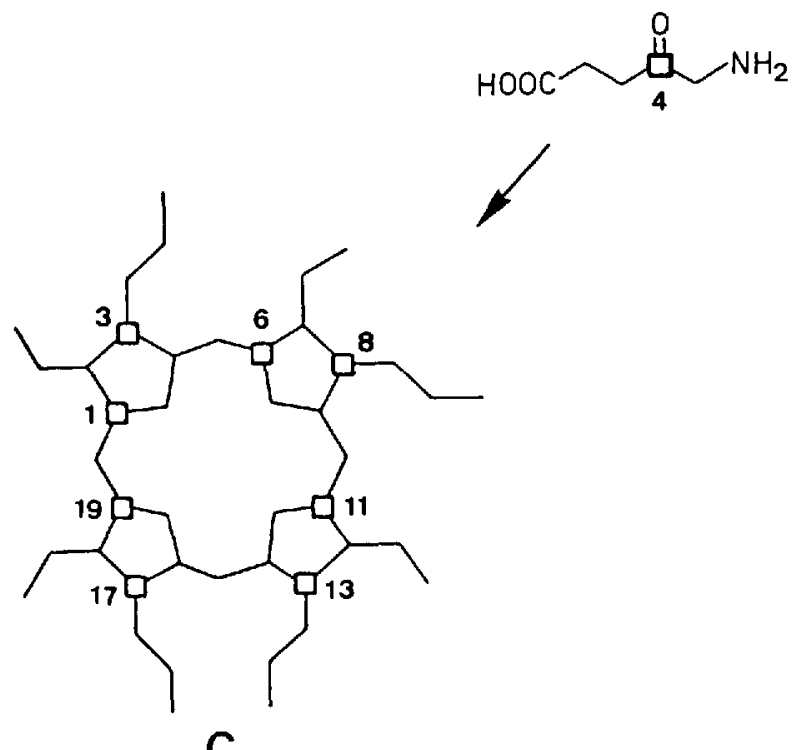

C

\section{Scheme 1}

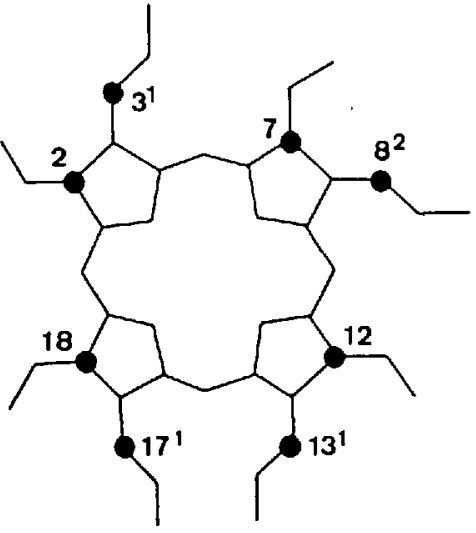

B<smiles>NCC(=O)OCC(=O)O</smiles>

ALA

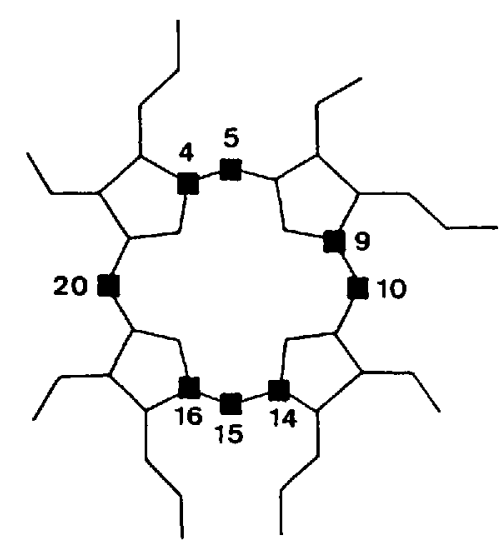

D 
Coenzyme F 430 - A Hydroporphinoid Nickel Complex from Methanogenic Bacteria

In 1978 Gunsalus and Wolfe [4] described the isolation of a yellow compound from Methanobacterium thermoautotrophicum which had been originally detected in chromatograms of cell extracts by LeGall [5]. The compound had a novel chromophore with an absorption maximum at $430 \mathrm{~nm}$ and, accordingly, was named factor F 430. In the beginning the new factor did not attract much attention. However the situation suddenly changed, when it was discovered that factor F 430 contained nickel [6]. Besides some Ni-containing proteins [7], this was the first example of a Ni complex of biological origin [8]. Thauer and coworkers speculated that factor F 430 might be a Ni-tetrapyrrole [6a]. By subsequent biosynthetic incorporation experiments with $\left[{ }^{14} \mathrm{C}\right]-\delta$-aminolevulinic acid (ALA), which is the biosynthetic precursor of all porphinoids and corrins found in nature, they were able to confirm their hypothesis [9a]. The detailed structure of factor $F 430$ was finally elucidated by joint efforts in the laboratories of Thauer at the University of Marburg and Eschenmoser at the ETH Zürich [10][11].

There were several problems that precluded a straightforward structure elucidation by the usual methods. Factor F 430 is a very polar, heat-labile, and oxygen-sensitive compound which is soluble only in $\mathrm{H}_{2} \mathrm{O}$ and highly polar organic solvents and therefore, difficult to purify. NMR spectroscopy in $\mathrm{D}_{2} \mathrm{O}$ or $\mathrm{CD}_{3} \mathrm{OD}$ did not provide any useful results, because $\mathrm{F} 430$ proved to be paramagnetic under these conditions. In addition, all attempts to prepare crystals suitable for $\mathrm{X}$-ray analysis failed.

Because of these difficulties, the structure of the porphinoid ligand was elucidated by using a derivative, formed by acidic methanolysis, rather than the parent compound. The methanolysis product, designated $F 430 \mathrm{M}$, was formed in high yield when partially purified $F 430$ samples were treated with TsOH in $\mathrm{MeOH}$ at 40 $50^{\circ}$ (Fig. I) [10 a]. F $430 \mathrm{M}$ is readily soluble in organic solvents such as $\mathrm{CH}_{2} \mathrm{Cl}_{2}$ and could be easily obtained in pure form by preparative TLC on $\mathrm{NaClO}_{4}$-coated silicagel plates. The essentially identical UV/ VIS and CD spectra of F 430 and F $430 \mathrm{M}$ demonstrated that the chromophore had not been affected during methanolysis (Fig. 1). In strictly anhydrous $\mathrm{CH}_{2} \mathrm{Cl}_{2}$ devoid of nucleophilic impurities, F $430 \mathrm{M}$ was found to be diamagnetic. Under these conditions, well-resolved ${ }^{1} \mathrm{H}$ - and ${ }^{13} \mathrm{C}$ NMR spectra, essential for a successful structure elucidation, could be obtained.

The constitution of F $430 \mathrm{M}$ was determined largely by NMR spectroscopy in combination with a series of biosynthetic labeling experiments. Thauer and coworkers had shown earlier that ALA and L-methionine can be incorporated into factor
F430 with high efficiency [9]. Feeding of $\left[{ }^{13} \mathrm{C}\right]$-ALA, specifically labeled either at $\mathrm{C}(2), \mathrm{C}(3), \mathrm{C}(4)$, or $\mathrm{C}(5)$, and $\left[\mathrm{CH}_{3}{ }^{-13} \mathrm{C}\right]-\mathrm{L}-$ methionine to cells of Methanobacterium thermoautotrophicum led to five differently labeled F430 samples which, after conversion to $\mathrm{F} 430 \mathrm{M}$, were analyzed by ${ }^{13} \mathrm{C}$ NMR spectroscopy. The spectra clearly showed that the F430 ligand is assembled from eight molecules of ALA and contains two methionine-derived Me groups. Presuming that factor $F 430$, as all other porphinoids, is formed via the well-established biosynthetic pathway leading from ALA to uroporphyrinogen III [12], the exact positions of the ${ }^{13} \mathrm{C}$ labels in the porphinoid ligand frame are readily predicted (Scheme 1). The labeling patterns allowed a rather straightforward interpretation of the ${ }^{13} \mathrm{C}$ NMR spectra of the labeled samples and of unlabeled F $430 \mathrm{M}$. Particularly instructive was the spectrum from the incorporation experiment with $\left[5-{ }^{13} \mathrm{C}\right]$-ALA. The observed ${ }^{13} \mathrm{C},{ }^{13} \mathrm{C}$ couplings between adjacent labeled $\mathrm{C}$-atoms were in full agreement with the characteristic arrangement of the ${ }^{13} \mathrm{C}$ labels in formula $\mathbf{D}$ and permitted direct unambiguous assignment of the signals of $\mathrm{C}(15)$ (uniquely situated between two labeled C-atoms) and $C(20)$ (isolated from the other labeled atoms).

The structure of the chromophore was deduced from NMR data and the UV/VIS spectrum (Fig. 1). Comparison with the UV/VIS spectra of a series of model compounds [13] indicated that factor F430 possessed a linear $\pi$-system spanning the range between three $\mathrm{N}$-atoms of the macrocycle. The electrophoretic proper- ties, the perchlorate band in the IR spectrum, and the fast-atom-bombardment (FAB) MS suggested an ionic structure for F $430 \mathrm{M}$, consisting of a monopositively charged Ni(II) complex with a molecular mass of $975\left({ }^{58} \mathrm{Ni}\right)$ and perchlorate as the counterion. The remaining ambiguities concerning the constitution of $\mathrm{F} 430 \mathrm{M}$ were finally resolved by a detailed ' $\mathrm{H}$ NMR analysis, making extensive use of nuclear Overhauser effect (NOE) difference spectroscopy (Fig.2). The results of this analysis also revealed the relative configuration at the six stereogenic centers in rings $A$ and $B$. The absolute configuration at these centers and at $C(12)$ and $C(13)$ in ring $C$ was determined by a series of chemical transformations correlating $\mathrm{F} 430 \mathrm{M}$ with reference compounds of known absolute configuration [10a,d]. The configuration at the remaining three stereogenic centers in ring $D$ could not be reliably assigned with the available date. There were some, though rather inconclusive, arguments suggesting a cis-arrangement of $\mathrm{H}-\mathrm{C}(19)$ and $\mathrm{H}-\mathrm{C}(4)$ (implying the $(S)$-configuration for $\mathrm{C}(19))$ [10a]. However, preliminary results from an $\mathrm{X}$-ray analysis of 12,13-diepi-F $430 \mathrm{M}$, an isomer produced by thermal isomerization of $\mathrm{F} 430$ [10c], and more recent NMR studies indicate the $(R)$-configuration for $\mathrm{C}(19)$ with an (alltrans)-arrangement of the three $\mathrm{H}$-atoms at $C(17), C(18)$, and $C(19)$ [14]. This implies that our original tentative assignment of the ring $D$ configuration [ 10 a] should be reversed.

After the structure of the porphinoid ligand system had been established for the

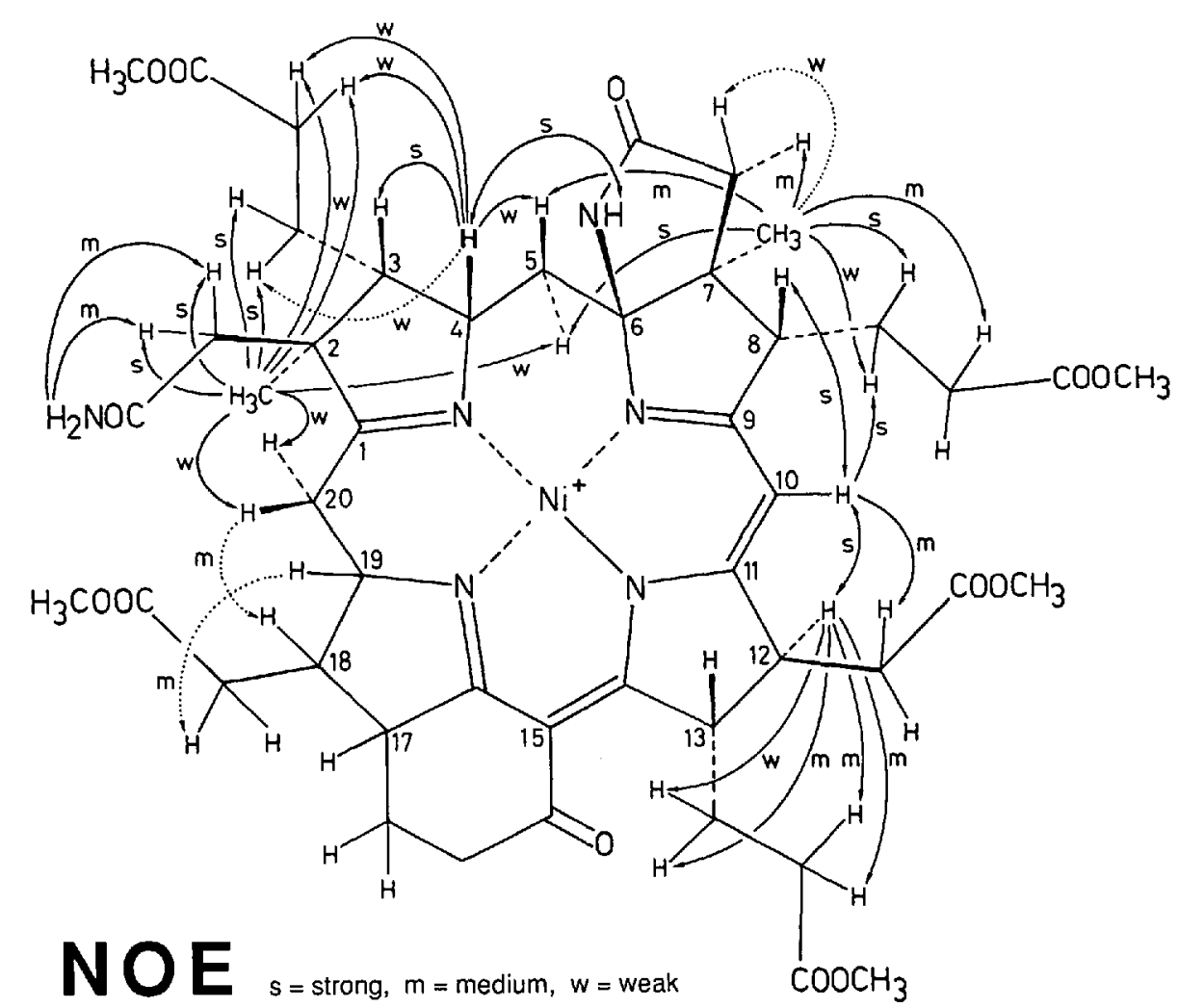

Fig. 2. Structure determination of F430M by nuclear Overhauser effect (NOE) difference spectroscopy ( $\rightarrow$ unambiguously assigned NOE; $\cdots>$ tentatively assigned NOE) 
methanolysis product $\mathrm{F} 430 \mathrm{M}$, the question arose, whether native factor F 430 contained any additional components which were lost upon extraction from the bacterial cells at $\mathrm{pH} 2$ or during methanolysis. Due to the particular properties of F430 discussed above, the structural analysis of non-derivatized F430 samples turned out to be a difficult task. Extensive rigorous investigations by Livingston et al. [10 b] eventually led to a rather unspectacular result: the parent factor $F 430$ turned out to be the penta-acid 2 corresponding to the pentamethyl-ester F $430 \mathrm{M} 1$.

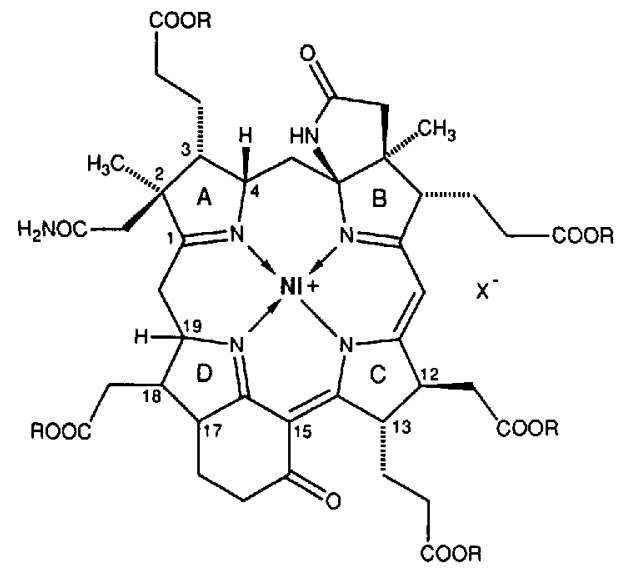

1 F430M $\left(\mathrm{A}=\mathrm{CH}_{3}, \mathrm{X}^{-}=\mathrm{ClO}_{4}^{-}\right)$

2 coenzyme F430 $(R=H)$

The role of factor $\mathrm{F} 430$ in methanogenic bacteria became evident when Wolfe and coworkers [15] identified F 430 as a component of the enzyme which catalyzes methane formation in these organisms. It was shown that dissociation of $F 430$ from the purified enzyme yielded the same species as had been obtained before by extraction of bacterial cells [16]. Therefore, the penta-acid 2 was termed coenzyme F 430 .

There are a number of unique structural features that distinguish coenzyme F430 from other tetrapyrroles. Its chromophore consists of a rather short, linear, enaminoid $\pi$-system, extending over only nine of the sixteen centers of the inner macroring, and has not been previously encountered in natural systems. Of all corrinoids and porphinoids found in nature, F 430 possesses the most highly saturated ligand system. Coenzyme F430 may be considered a derivative of a tetrahydro-corphin. Corphins [17], as indicated by their name, are structural hybrids of corrins and por-
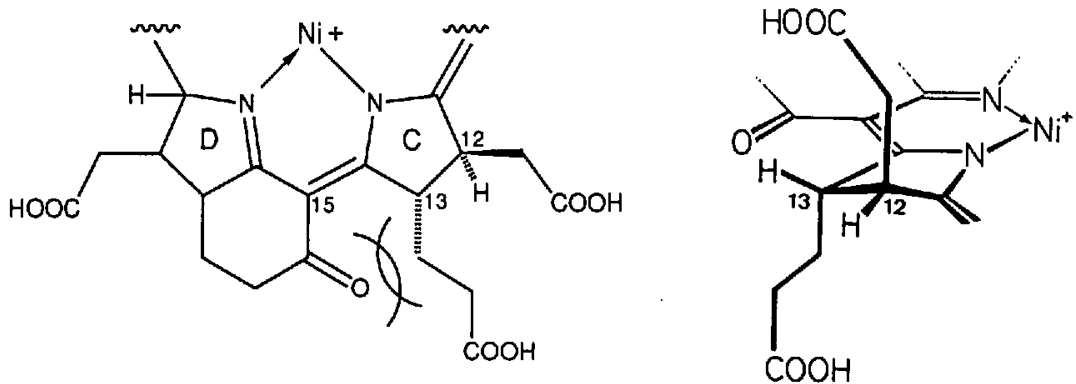

Fig. 3. Ring-C conformation of coenzyme F430

phyrins, with a porphinoid ligand skeleton and a linear, corrinoid $\pi$-system. Further noteworthy structural elements are the isolated imine double bond in ring $A$, the fivemembered lactam ring, reminiscent of the so-called 'yellow corrinoids' [18], and the carbocyclic ring formed by the propionicacid side chain in ring $D$. This additional ring is of considerable consequence to the chemical properties of coenzyme F 430 .

The stabilizing conjugative interaction between the electron-withdrawing $\mathrm{C}=\mathrm{O}$ group on the carbocyclic ring and the electron-rich chromophore system results in reduction of the electron density at the chromophore $\mathrm{N}$-atoms and, therefore, is expected to weaken the $\mathrm{Ni}-\mathrm{N}$ bonds and to increase the electrophilicity of the $\mathrm{Ni}$ ion. This is of particular importance with regard to the redox properties of coenzyme $\mathrm{F} 430$ and the axial reactivity at the Ni center (see below). In addition, the carbocyclic ring has a distinct effect on the conformation of rings $C$ and $D$. Molecular models indicate an unfavorable steric interaction between the $\mathrm{C}=\mathrm{O}$ group of the carbocyclic ring and the adjacent propionic-acid side chain, when ring $\mathrm{C}$ assumes a half-chair conformation with the propionic-acid side chain in a pseudoequatorial position ( $c f$. Fig. 3). Therefore, the inverse half-chair conformation of ring $C$ with a pseudodiaxial arrangement of the two side chains is expected to be favored. The predicted pseudodiaxial arrangement of the propionic-acid and the acetic-acid side chains in ring $C$ is confirmed by the 'H-NMR data of $F 430 \mathrm{M}[10 \mathrm{a}]$. The particular conformational behavior of ring $C$ has important consequences with regard to the reactivity at the ring $C$ periphery and at the $\mathrm{Ni}$ center (see the detailed discussions in $[10 \mathrm{a}, \mathrm{c}][11]$ [17]).

One of the conspicuous properties of coenzyme $\mathrm{F} 430$ is its distinct axial reactiv-<smiles></smiles>

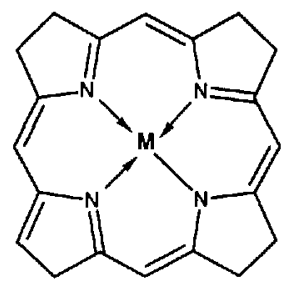

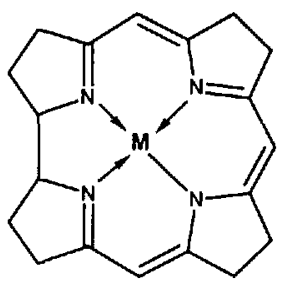

PORPHYRIN ity at the Ni center [10c][11][17][21]. In the presence of nucleophiles, such as imidazole, or in moderately nucleophilic solvents like $\mathrm{MeOH}$ or $\mathrm{H}_{2} \mathrm{O}$, the paramagnetic penta- or hexacoordinate forms predominate $[10 \mathrm{c}][11][21]$. The strong tendency of the $\mathrm{Ni}$ ion to fill the axial coordination sites with additional ligands is a general attribute of corphinoid $\mathrm{Ni}$ (II) complexes, which clearly distinguish themselves from corrinoid $\mathrm{Ni}$ (II) complexes in this respect [17][19][20].

The contrasting behavior of corphinoid as compared to corrinoid $\mathrm{Ni}$ (II) complexes has been attributed to the larger coordination hole diameter in corphin-type ligands as a consequence of their larger macrocyclic ring [17] [19] [20b] [22]. Whereas the corrin macrocycle perfectly accommodates a tetracoordinated low-spin Ni(II) ion, the $\mathrm{Ni}-\mathrm{N}$ bonds in a corphinoid low-spin complex would become unfavorably long, if the ligand assumed an unstrained conformation. For that reason, corphin-type ligands adopt a distorted saddle-shaped conformation in low-spin $\mathrm{Ni}(\mathrm{II})$ complexes, with concomitant shortening of the $\mathrm{Ni}-\mathrm{N}$ bonds [17] [19]. This deformation permits the complex to adjust the coordination geometry to the specific requirements of a low-spin Ni(II) ion; however, at the same time it builds conformational strain. The strain energy associated with the saddle-shaped deformation provides a driving force for the addition of axial ligands, as this leads to longer $\mathrm{Ni}-\mathrm{N}$ bonds and thereby allows the ligand to relax to a less strained conformation. The electronwithdrawing $\mathrm{C}=\mathrm{O}$ group at the carbocyclic ring and the particular conformational behavior of ring $C$ (see above) are additional factors contributing to the pronounced electrophilicity of the $\mathrm{Ni}(\mathrm{II})$ ion in coenzyme F430 [10a,c] [11] [17], a property which is likely to be related to its biological function.

As mentioned before, coenzyme F430 plays a central role in the energy metabolism of methanogenic bacteria [23]. It is one of the coenzymes of methyl-coenzyme $M$ reductase, a complex enzyme system which catalyzes methane formation from $S$-methyl-coenzyme M (Scheme 2) [15] [23] [24]. In addition to coenzyme F430 and coenzyme $\mathrm{M}$, a third low-molecularweight component, 7-mercaptoheptanoyl$O$-phosphothreonine (HS-HTP) [25], is required in this process. It was recently 
Scheme 2. Methane formation in methanogenic bacteria [23] [24] [26] [27] (THMPT = tetrahydro-methanopterin [57])

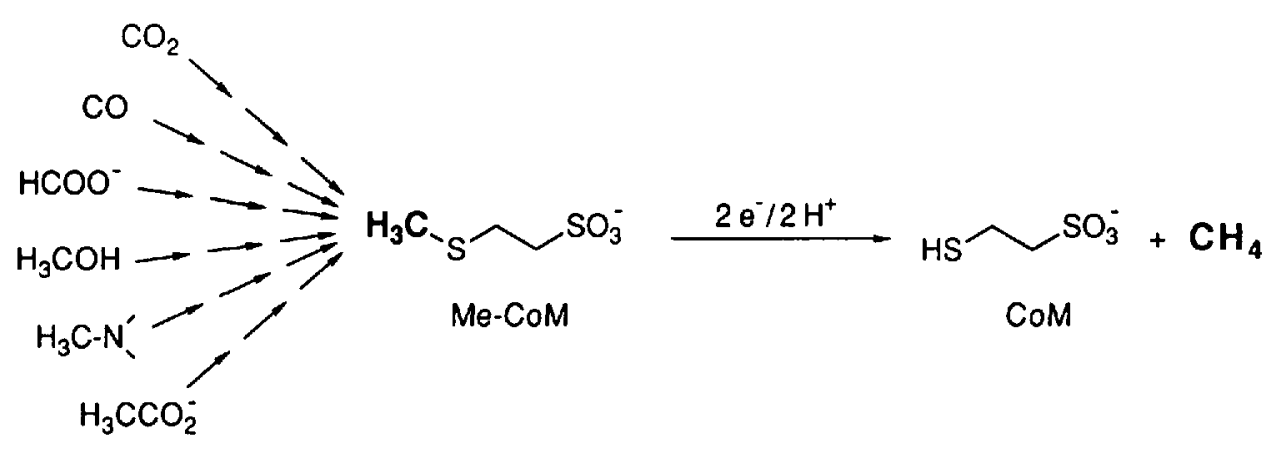

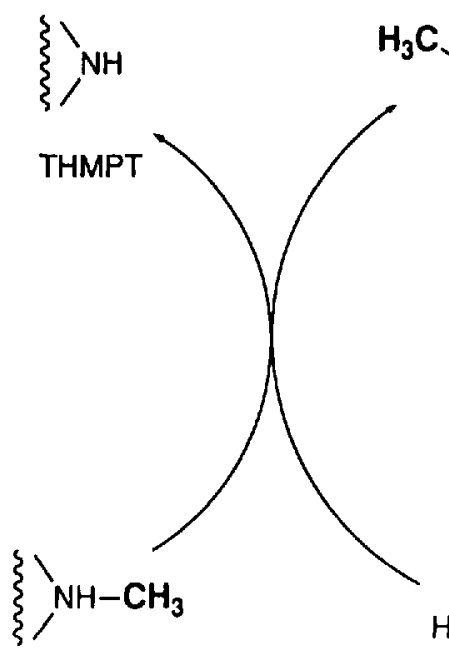

Me-THMPT<smiles>CSCC[SH](=O)[O-]</smiles>

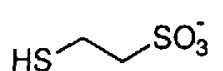

CoM<smiles>C[C@H](OP(=O)([O-])O)[C@H](NC(=O)CCCCCCS)C(=O)[O-]</smiles>

HS-HTP

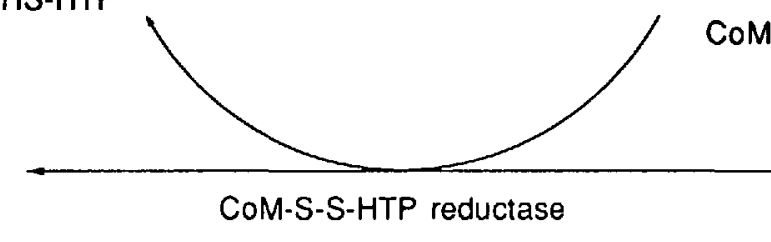

$\mathrm{CH}_{4}$<smiles>C[C@H](NC(=O)CCCCCCSSCCS(=O)(=O)[O-])[C@@H](C)C(=O)[O-]</smiles>

$2 e^{\cdot} / 2 H^{+}$ shown that the reductive cleavage of $S$ methyl-coenzyme $M$ proceeds in two steps. The first step, catalyzed by the F430-containing enzyme, produces methane and the heterodisulfide derived from coenzyme $M$ and HS-HTP (Scheme 2) [26]. The subsequent reduction of the heterodisulfide is mediated by a different enzyme and regenerates coenzyme M and HS-HTP [27].

The specific role of coenzyme F430 in the cleavage of $S$-methyl-coenzyme $\mathrm{M}$ ist still unknown. Considering the nature of the enzymatic process (Scheme 2), it seems reasonable to speculate that reduced forms of coenzyme $\mathrm{F} 430$ might be involved. In this context, the redox chemistry of F430M has been investigated [28] [29]. Cyclic voltammetry in DMF, MeCN, and THF showed that $\mathrm{F} 430 \mathrm{M}$ undergoes clean, reversible one-electron reduction at $-1.3 \mathrm{~V}$ vs. the ferricenium/ferrocene couple (Scheme 3). This is the same potential range in which vitamin $B_{12}$ is converted from the $\mathrm{Co}$ (II) to the $\mathrm{Co}$ (I) form [30]. The one-electron reduction product of $\mathrm{F} 430 \mathrm{M}$ was characterized by UV/VIS and ESR spectroscopy (Fig.4). For this purpose, F430M was reduced on a preparative scale with dilute $\mathrm{Na} / \mathrm{Hg}$ in THF. The ESR spectrum in frozen THF solution, shown in Fig. $4 b$, is highly characteristic for an approximately square planar $\mathrm{Ni}(\mathrm{I})$ complex with the unpaired electron localized in an orbital having $\mathrm{d}_{x 2-y_{2}}$ character.

The observation that one-electron reduction leads to a metal-centered radical and not to a ligand-centered $\pi$-radical may be rationalized as a consequence of the distinct electrophilicity of the metal center in

Scheme 3. One-electron reduction of coenzyme F430 pentamethyl ester

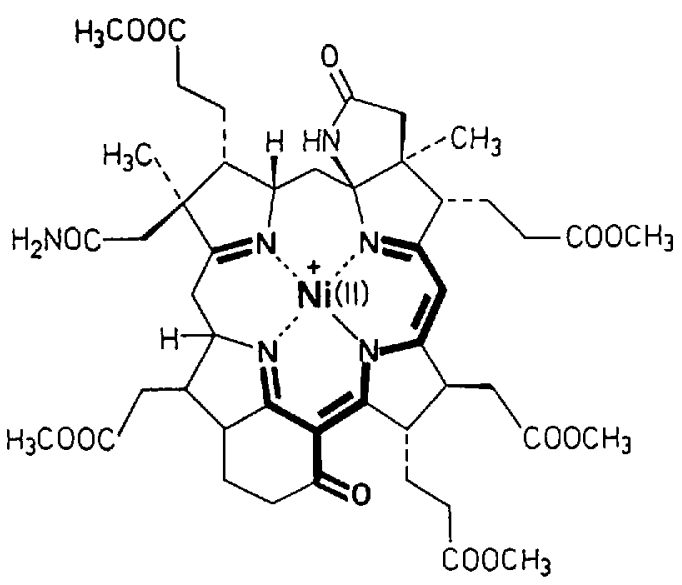

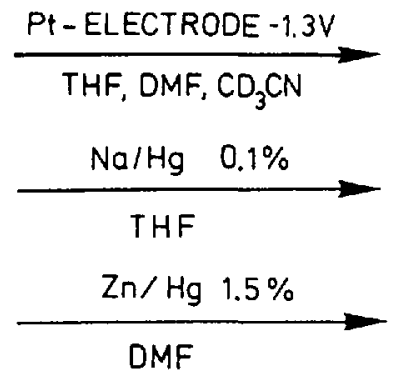

DMF

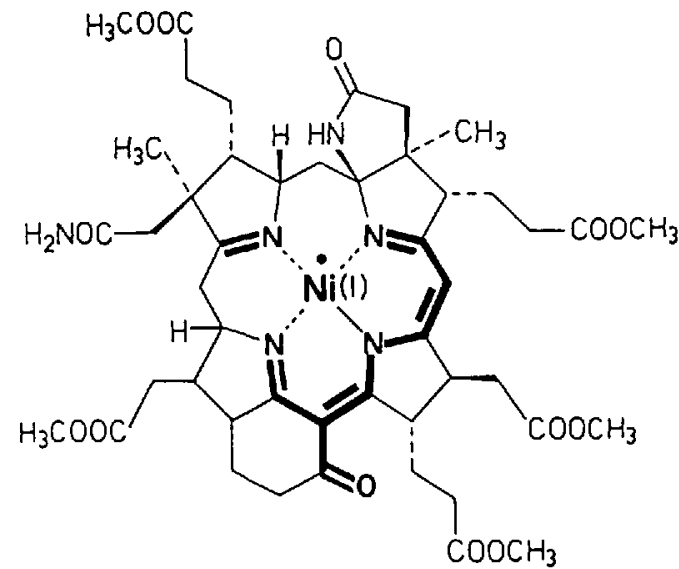


$\epsilon \cdot 10^{-4}$

a)

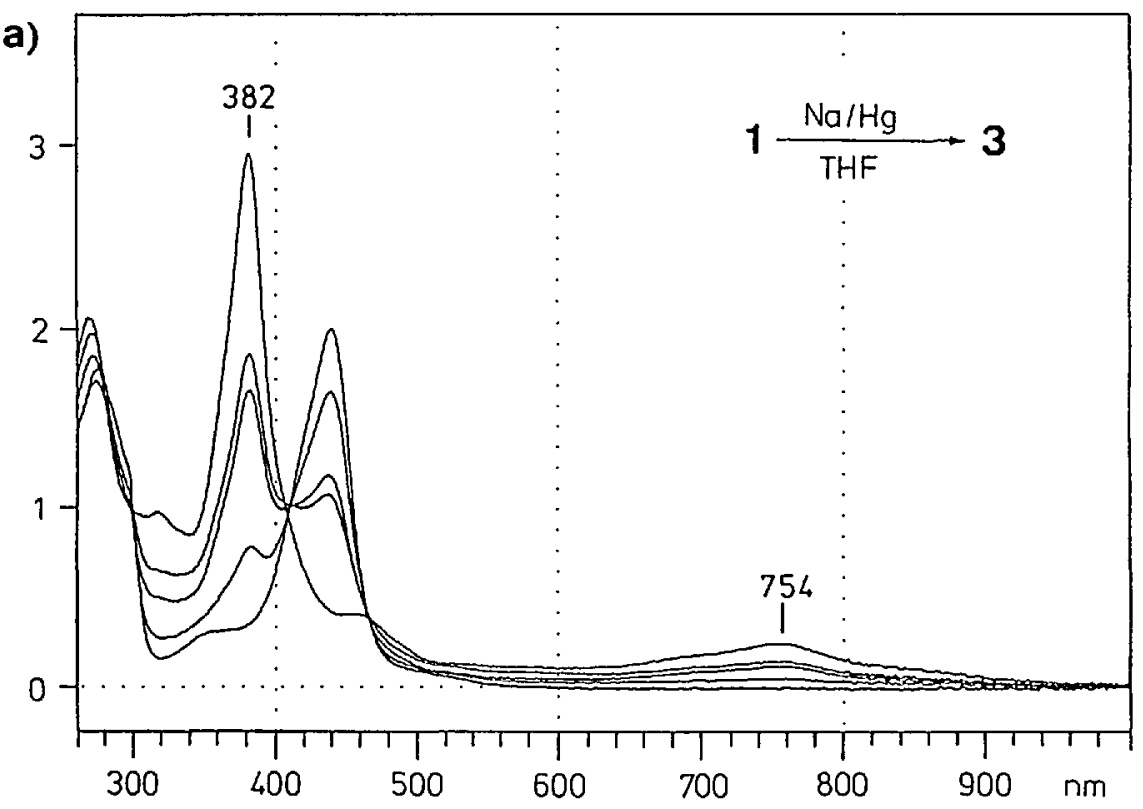

b)

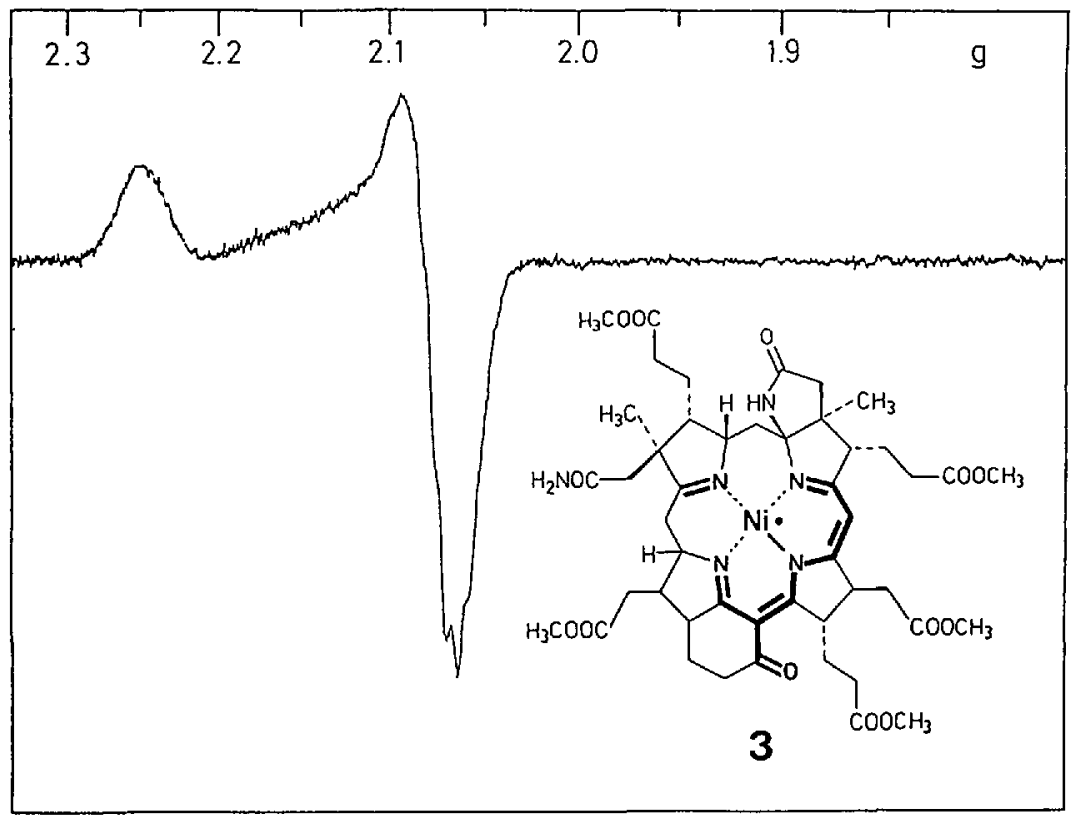

Fig. 4. a) One-electron reduction of F430M (1) monitored by UV/VIS spectroscopy; b) ESR spectrum of $\mathrm{Ni}$ (I) F430M (3) in frozen THF at $88 \mathrm{~K}$ [28] [29]

F430 (see above). The same factors that promote the addition of axial ligands to the $\mathrm{Ni}(\mathrm{II})$ ion are expected to facilitate its reduction to the $\mathrm{Ni}(\mathrm{I})$ state, as both processes lead to longer equatorial $\mathrm{Ni}-\mathrm{N}$ bonds. In addition, the $\pi$-system in the F430 ligands is restricted to fewer centers than in other natural porphinoids and corrins. Therefore, formation of a $\pi$-radical should be less favorable than in more extendend $\pi$-systems [31].

ESR studies by Albracht et al. [32] with intact cells indicate that the $\mathrm{Ni}$ ion in coenzyme F430 can change its oxidation state under physiological conditions. Depending on the conditions, up to six different ESR signals attributed either to $\mathrm{Ni(I)}$ or $\mathrm{Ni}$ (III) forms of coenzyme F430 could be detected. One of those signals closely re-

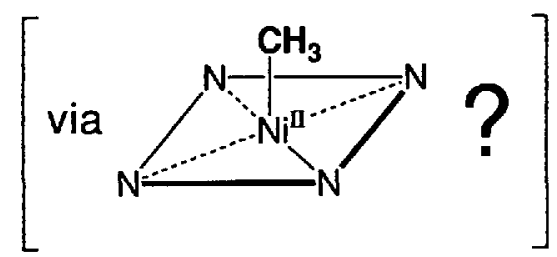

sembled the signal obtained upon reduction of F430M to the Ni(I) form (Fig.4) [33]. These findings strongly suggest that Ni(I) F430 plays a role in the reductive cleavage of the $\mathrm{CH}_{3}-\mathrm{S}$ bond of methylcoenzyme M (Scheme 2).

In this context the reactivity of $\mathrm{Ni}(\mathrm{I})$ F430M toward compounds containing a $\mathrm{CH}_{3}$ group bound to $\mathrm{S}, \mathrm{O}$, or halogen was investigated [29] [34]. Ni(I) F430M, prepared by reduction with $\mathrm{Zn} / \mathrm{Hg}$ (Scheme 3 ), instantaneously reacted with $\mathrm{CH}_{3} \mathrm{I}$ in DMF at $-60^{\circ}$ to give $\mathrm{CH}_{4}$ in high yield. TsOMe proved to be much less reactive, but at $25^{\circ}$ was also converted to $\mathrm{CH}_{4}$. Methyl thioethers such as coenzyme $\mathrm{M}$ or $\left(\mathrm{CH}_{3}\right)_{2} \mathrm{~S}$ were found to be inert under these conditions. However, the more electrophilic $\mathrm{CH}_{3}-\mathrm{S}$ bond of methylsulfonium ions was cleaved by Ni(I) F430M. Treatment of trimethylsulfonium tetrafluoroborate with liquid $\mathrm{Zn} / \mathrm{Hg}$ in DMF in the absence of $F 430 \mathrm{M}$ produced only trace amounts of $\mathrm{CH}_{4}$. After addition of a catalytic amount of $\mathrm{F} 430 \mathrm{M}$, a very clean, essentially quantitative reaction to $\left(\mathrm{CH}_{3}\right)_{2} \mathrm{~S}$ and $\mathrm{CH}_{4}$ was observed. In the same way, the cyclic sulfonium salt shown in Scheme 4 was converted to $\mathrm{CH}_{4}$, tetrahydrothiophene, and $\mathrm{MeSBu}$. The observed product ratio shows a distinct preference for cleavage of the $\mathrm{Me}-\mathrm{S}$ bond over cleavage of an $\mathrm{S}$-alkyl bond in the five-membered ring.

The reaction formally requires two electrons and one proton. In neat DMF, residual $\mathrm{H}_{2} \mathrm{O}$ was identified as the proton source. Reduction in the presence of $\mathrm{Me}_{2} \mathrm{CHOD}$ or $\mathrm{Et}_{3} \mathrm{NDCl}$ led to $\mathrm{CH}_{3} \mathrm{D}$, whereas, in neat perdeuterated DMF, no $\mathrm{D}$ was incorporated into $\mathrm{CH}_{4}$ [29] [34]. These findings clearly indicate that the step in which $\mathrm{CH}_{4}$ is liberated involves a proton transfer rather than $\mathrm{H}$-atom abstraction. This is consistent with a reaction pathway proceeding via a Me-Ni species [35] which is then protonated to give methane and Ni(II) F430M

In view of the high efficiency of Ni(I) F430M as a catalyst in the reductive cleavage of $\mathrm{CH}_{3}-\mathrm{S}$ bonds in sulfonium ions, it is tempting to propose a similar role for coenzyme F430 in the reductive cleavage of methyl-coenzyme $M$. However, there are still several open questions concerning the

Scheme 4<smiles>C[S+]1CCCC1</smiles>

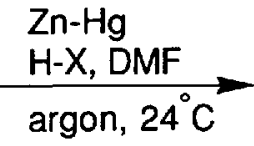

F430M

(1 $\mathrm{mol} \%)$<smiles>C1CCSC1</smiles>

$70 \%$
$\mathrm{CH}_{4}+$

$70 \%$<smiles>CCCCSC</smiles>

$30 \%$ 


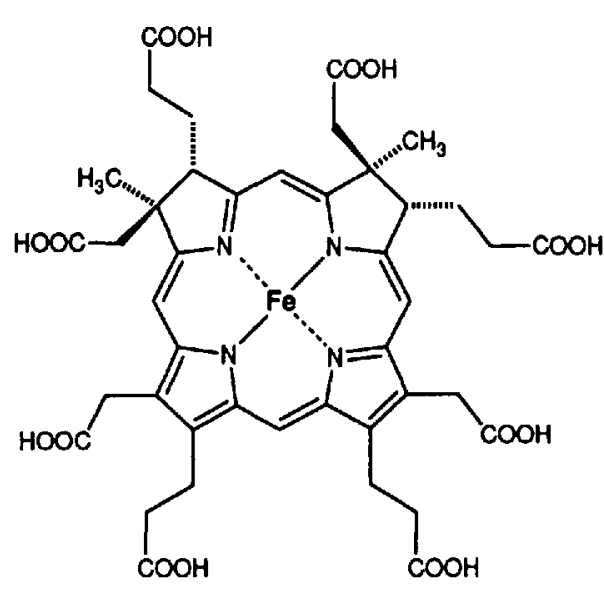

SIROHEME

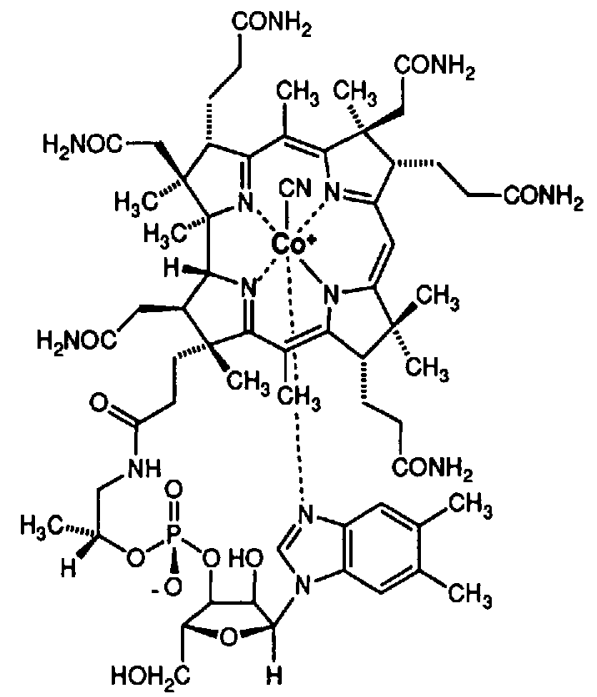

VITAMIN $B_{12}$<smiles></smiles>

Fig. 5. Structure of 1,9-disubstituted $\mathrm{C}_{2}$-symmetric semicorrin ligands mechanism of the enzymatic process, such as the apparent lack of reactivity of $\mathrm{Ni}(\mathrm{I})$ F430M towards methyl-coenzyme $M$. It remains to be shown, whether a more realistic model reaction can be developed that would allow reductive cleavage of non-activated methyl thioethers.

Structural formulas of coenzyme F430 and its structurally as well as biogenetically closest relatives, siroheme and vitamin $B_{12}$ are shown below. Although they belong to the same family, the porphinoid ligand of siroheme, the corrin macrocycle of vitamin $\mathrm{B}_{12}$, and the corphinoid F430 ligand each provide a very different steric and electronic environment for the coordinated metal ion. The three metal complexes illustrate how uroporphyrinogen III, the common macrocyclic precursor of all natural tetrapyrroles [12], can be modified in living systems in a variety of ways. By this route, a series of specialized ligands is generated which is used for accommodating the various metal ions needed for catalysis of certain biochemical reactions [3]. As discussed for coenzyme F430, each of these ligands influences the properties of the complexed metal ion in a distinct way, so that the resulting reactivity pattern meets the specific requirements of enzymatic catalysis.

\section{Enantioselective Catalysis with Tailor- Made Semicorrin Metal Complexes}

The various metallocoenzymes found in nature beautifully demonstrate how the course of a metal-catalyzed reaction can be efficiently controlled by a properly de-
COENZYME F430

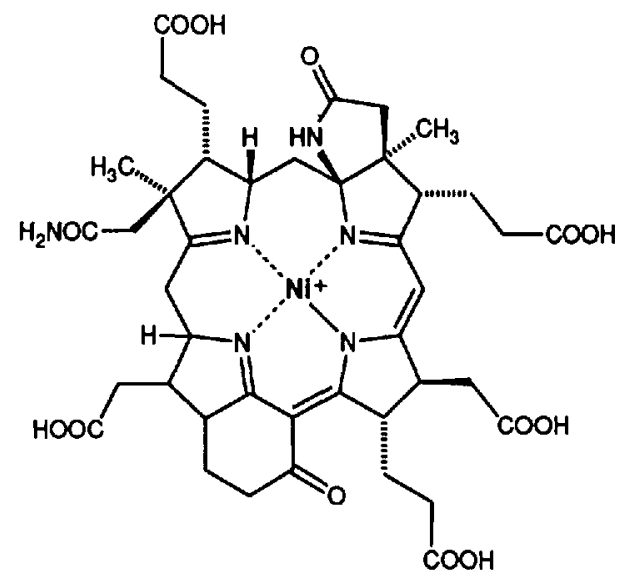

Scheme 5<smiles>N#CCC(=O)OCCC(=O)N1CCC(=O)N1</smiles><smiles>[R]C1CC=C2C(C#N)=C3CCC([R])N3NN21</smiles>

signed organic ligand. However, there are also numerous examples of synthetic metal catalysts which illustrate this principle. An area of research where the concept of ligand-based selectivity control has proved to be most fruitful is enantioselective catalysis. In the past two decades, a number of

Scheme 6<smiles>O=C1CC[C@@H](C(=O)O)N1</smiles>

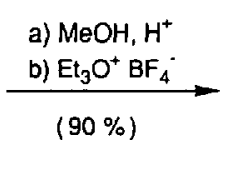

$(-) \cdot 5$<smiles>COC(=O)[C@@H]1CCC2=C(C#N)C3=[N+](CN21)[C@@H](C(C)=O)CC3</smiles>

$(-)-6$<smiles>CC(=O)[C@H]1CCC([O-])=N1</smiles>

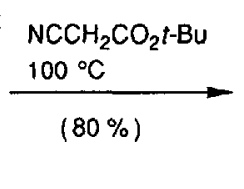<smiles>CCC</smiles>

\section{$\mathrm{CF}_{3} \mathrm{CO}_{2} \mathrm{H}$}

$\mathrm{ClCH}_{2} \mathrm{CH}_{2} \mathrm{Cl}$ $65^{\circ} \mathrm{C}$

$(65.75 \%)$<smiles>CCOC(=O)C(C#N)=C1CC[C@@H](C(C)=O)N1</smiles><smiles>COC(=O)[C@@H]1CC/C(=C\C#N)N1</smiles>

$(E / Z \sim 1: 1)$

(30-40\% from (-)-5) 
Scheme 7

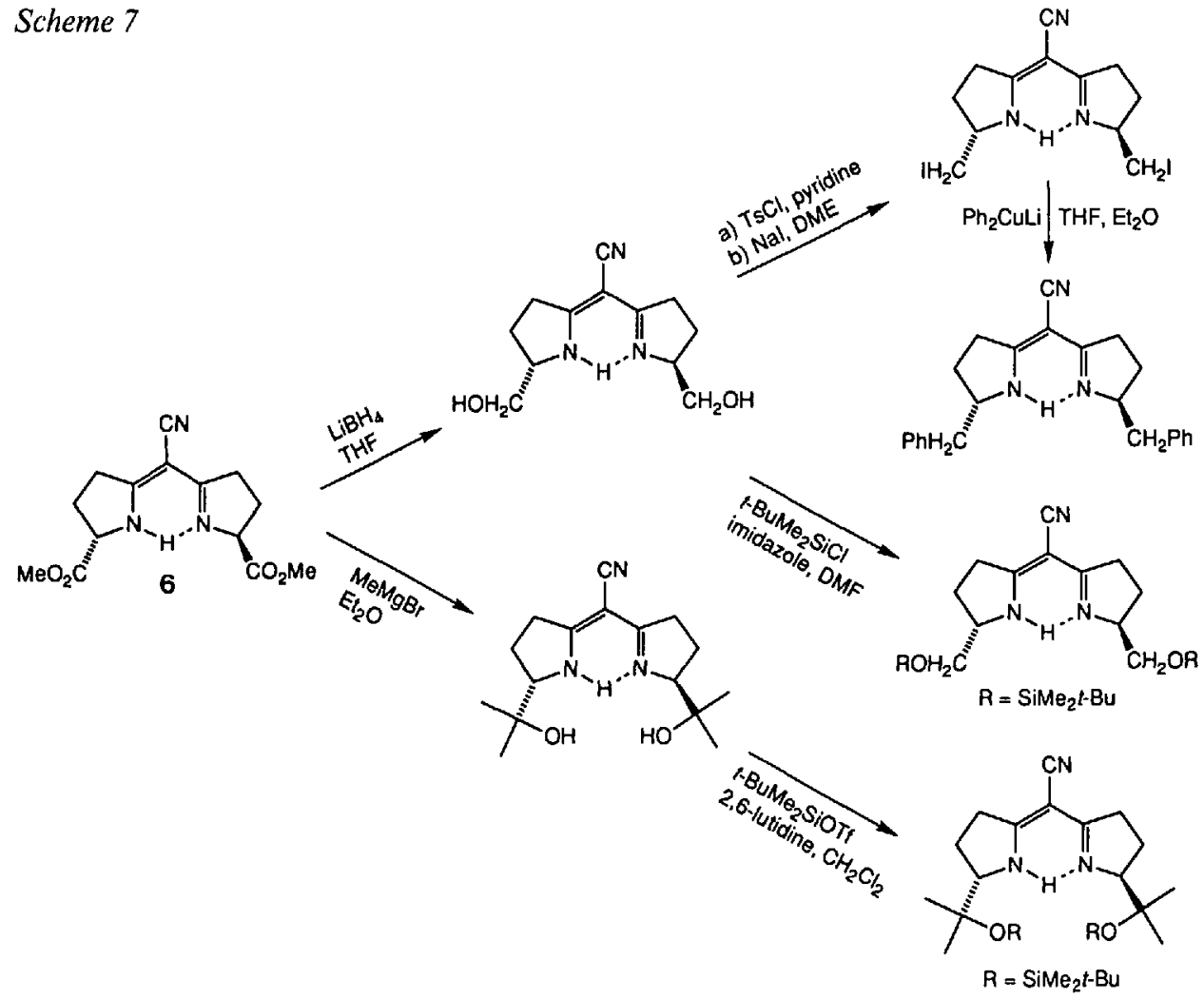

chiral ligands have been found which allow a metal-catalyzed process to be directed in such a way that one of two enantiomeric products is formed with high preference over the other [36]. Well known examples are the Sharpless epoxidation [37] and enantioselective hydrogenation with chiral $\mathrm{Rh}$ [38] and $\mathrm{Ru}[39]$ phosphine complexes.
Inspired by the structures of hydroporphinoid and corrinoid metal complexes, we have recently developed a route to chiral $C_{2}$-symmetric semicorrins [40] (Fig.5), a class of bidentate $\mathrm{N}$ ligands specifically designed for enantioselective control of metal-catalyzed reactions [41]. As discussed in the following, semicorrins of this type are readily obtained in enantiomerically pure form and should be well suited for a wide range of applications in enantioselective catalysis.

Fig. 5 emphasizes the particular structural features of 1,9-disubstituted $C_{2}$-symmetric semicorrins that led us to investigate their potential as ligands for the stereocontrol of metal-catalyzed reactions. The semicorrin framework is conformationally rather rigid and contains a vinylogous amidine system with ideal geometry for coordinating a metal ion. The substituents at the stereogenic centers are located in close proximity to the coordination site; they shield the metal ion from two opposite directions and, therefore, are expected to exert a strong influence on the stereochemical course of a reaction taking place in the coordination sphere. The conformational rigidity of the ligand system and its $C_{2}$ symmetry [42] restrict the number of possible catalyst-substrate arrangements as well as the number of competing diastereoisomeric transition states. Moreover, these structural characteristics simplify the problem of predicting the threedimensional structure of the catalyst. This greatly facilitates an analysis of the individual interactions between catalyst and substrate which determine the selectivity of a metal-catalyzed process and should allow a rather straightforward, rational approach to the problem of designing an enantioselective catalyst.

Semicorrins have been previously prepared as intermediates in the synthesis of
Scheme 8<smiles>[R]OCOC(=O)OC(C)(C)C</smiles>

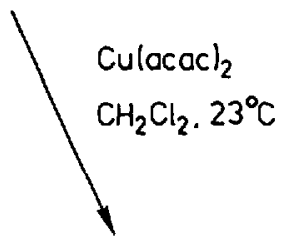

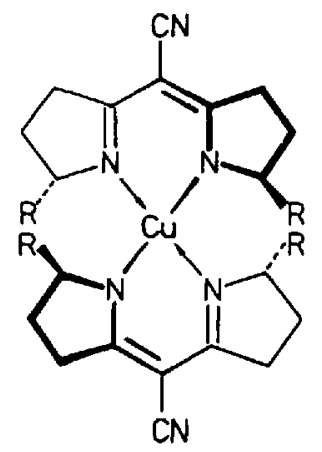

$\mathrm{R}=\mathrm{COOMe}$ $\mathrm{R}=\mathrm{CH}_{2} \mathrm{OSiMe}_{2} \mathrm{tBu}$

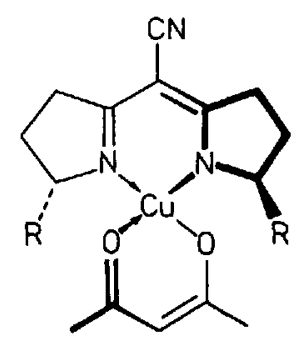

$R=$ COOMe

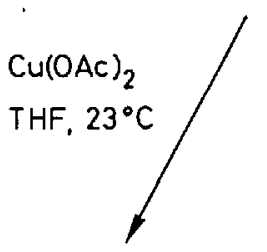<smiles></smiles>

$\mathrm{R}=\mathrm{CMe}_{2} \mathrm{OH}$

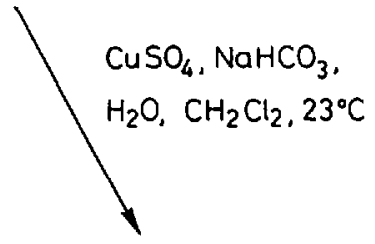

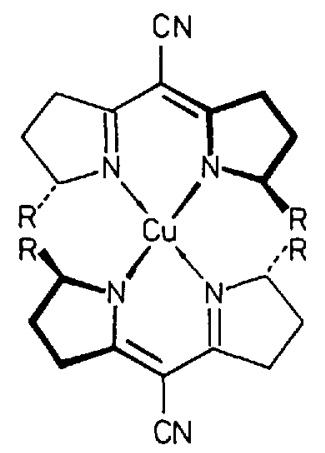

$\mathrm{R}=\mathrm{CMe}_{2} \mathrm{OH}$ 
Scheme 9
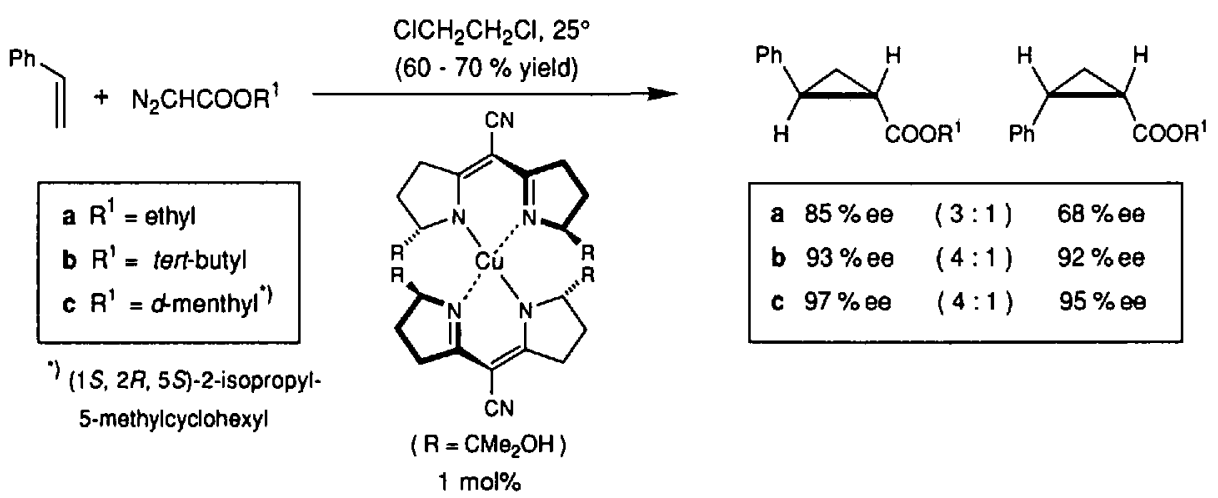

\begin{tabular}{|c|c|c|}
\hline $85 \% \theta \theta$ & $(3: 1)$ & $68 \% \theta \theta$ \\
\hline 93 & $(4: 1)$ & $92 \%$ ee \\
\hline $97 \%$ & $(4: 1)$ & $95 \%$ \\
\hline
\end{tabular}

corrinoid and hydroporphinoid compounds [43] [44]. They can be easily synthesized from appropriate butyrolactam derivatives via the classic routes devised by Eschenmoser [43]. This approach is particularly well suited for the synthesis of chiral $C_{2}$-symmetric semicorrins 4 , starting from pyroglutamic acid (5), a moderately priced compound which is commercially available in both enantiomeric forms (Scheme 5).

The actual synthesis, which is well suited for producing multigram quantities of semicorrins, is summarized in Scheme 6 [45]. The overall yield of crystalline, enantiomerically pure diester 6 , based on pyroglutamic acid (5), ranges between 30 and $40 \%$. The diester 6 is a versatile precursor which can be easily converted to a variety of different semicorrins (Scheme 7) [45] [46]. Variation of the substituents at the stereogenic centers allows the ligand structure to be adjusted to the specific requirements of a particular application and also provides a means for optimizing the selectivity of a catalyst in a systematic manner.

As expected for ligands of this type, semicorrins readily form chelate complexes with a variety of metal ions such as $\mathrm{Co}(\mathrm{II}), \mathrm{Ni}(\mathrm{II}), \mathrm{Pd}(\mathrm{II})$, or $\mathrm{Cu}(\mathrm{II})$ [45] [47] [48]. This is illustrated in Scheme 8 which summarizes the preparation of a series of (semicorrinato) $\mathrm{Cu}$ (II) complexes [45] [48]. Depending on the structure of the ligands and the specific reaction conditions, either mono- or bis(semicorrinato) complexes are obtained.

The first successful application of chiral semicorrin ligands was found for the metal-catalyzed cyclopropanation of olefins with diazo compounds. (Semicorrinato) $\mathrm{Cu}$ complexes proved to be efficient
Scheme 10
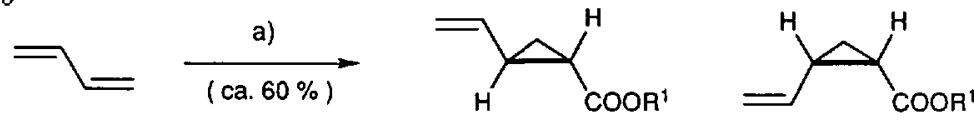

$$
97 \% \theta e
$$

(63:37)
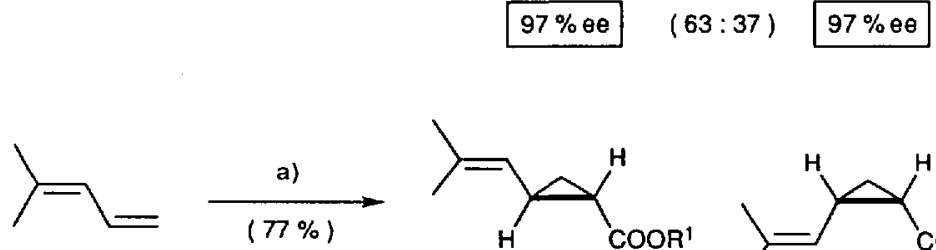<smiles>CC(C)=CCC=CC(=O)O</smiles><smiles>CC(C)=CC=CC(=O)O</smiles>

$$
97 \% \text { ee }
$$

$(63: 37)$
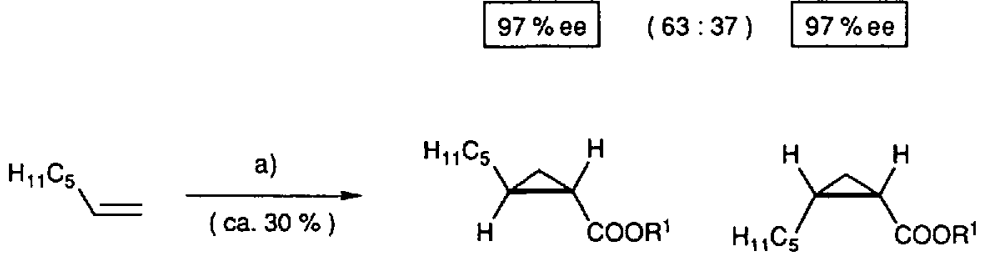

$92 \% \theta$

(82:18)

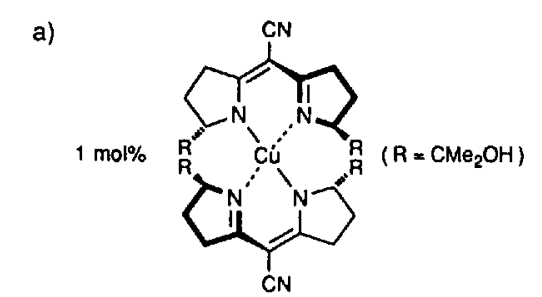

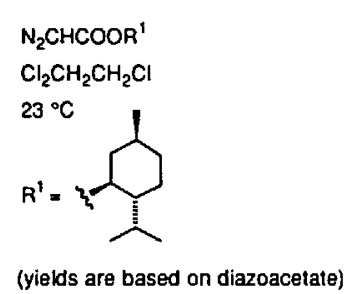

catalysts for reactions of this type and allowed the preparation of cyclopropanes in high enantiomeric purity [49]. The highest enantioselectivities were obtained using the ligand shown in Scheme 9, carrying bulky $\mathrm{HOMe}_{2} \mathrm{C}$-groups at the stereogenic centers. In the cyclopropanation of styrene with alkyl diazoacetates, the enantiomeric purity of the trans-product ranged between 85 and $97 \%$ ee, depending on the structure of the diazo compound. This exceeds the enantiomeric excesses previously observed in this reaction with other types of catalysts [41] [50] [51]. As illustrated in Scheme 10, terminal olefins in general are converted to cyclopropanes with excellent enantioselectivity, whereas non-terminal olefins give less favorable results. Intramolecular cyclopropane formation of $\alpha$-diazo-alkenyl ketones and the cyclopropanation of $(E)$-disubstituted olefins with $\mathrm{CH}_{2} \mathrm{~N}_{2}$ were also briefly examined. The selectivities obtained were encouraging, ranging between $70 \%$ and $80 \%$ ee [41] [48].

The bis(semicorrinato)copper(II) complex shown in Schemes 9 and 10 is not the actual species which catalyzes cyclopropane formation. To produce an active catalyst, the complex must first be activated, either by brief heating in the presence of the diazo compound or by reduction with phenylhydrazine [48] [49b]. All evidence that we have obtained so far indicates that the actual catalytically active species is a mono(semicorrinato) $\mathrm{Cu}(\mathrm{I})$ complex [41] [49b]. (For a discussion of the mechanism and a tentative model rationalizing the stereoselectivity of (semicorrinato)copper catalysts, see [41] [49b].)

Another type of reaction that can be efficiently controlled by semicorrin ligands is shown in Scheme 11 [41] [52]. In the presence of catalytic amounts of (semicorrinato)Co complexes, formed in situ from $\mathrm{CoCl}_{2}$ and the corresponding ligand, and with $\mathrm{NaBH}_{4}$ as reducing agent, $\alpha, \beta$-unsaturated carboxylic esters are enantioselectively reduced at the $\mathrm{C}=\mathrm{C}$ bond to give the corresponding saturated esters. The best results were obtained with the silyloxymethyl-substituted ligand $\mathbf{1 0}$ in a mixture of EtOH and DMF as solvent and with careful exclusion of $\mathrm{O}_{2}$. The reduction of the $(E)$ - and $(Z)$-isomers 7 and 9 , using 1 mol- $\%$ of catalyst, was remarkably clean and proceeded to completion within 1-2 days at room temperature. In several experiments, the enantiomeric excesses of the products $(+)-8$ and $(-)-8$ consistently ranged between 93 and $95 \%$. The semicorrin ligand, which upon workup forms a (catalytically inactive) bis(semicorrinato)Co complex, can be recovered after decomplexation with $\mathrm{AcOH}$.

Scheme 12 shows some additional examples of (semicorrinato)Co-catalyzed reductions. With the exception of the Ph-substituted compounds 13 and 14 , all substrates investigated so far react with excellent enantioselectivity. Geranic-acid ethyl ester $(11)$ and the corresponding $(Z)$-isomer 12 
Scheme 11<smiles>CCOC(=O)C=C(C)CCc1ccccc1</smiles>

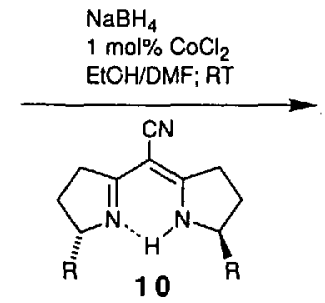<smiles>CCOC(=O)C[C@@H](C)CCc1ccccc1</smiles><smiles>CCOC(=O)/C=C(/C)CCc1ccccc1</smiles>

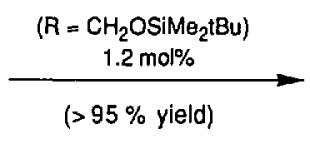<smiles>CCOC(=O)C[C@@H](C)CCc1ccccc1</smiles>

Scheme 12. (Semicorrinato) cobalt-catalyzed reduction with $\mathrm{NaBH}_{4}$<smiles>CCOC(=O)/C=C(\C)CCC=C(C)C</smiles>

11<smiles>CCOC(=O)/C=C(/C)CCC=C(C)C</smiles><smiles>CCOC(=O)C=C(C)c1ccccc1</smiles><smiles>CCOC(=O)/C=C(/C)c1ccccc1</smiles>

14<smiles>CCOC(=O)C=C(C)C(C)C</smiles>

15<smiles>CCOC(=O)/C=C(/C)C(C)C</smiles>

16

$$
\underset{(95 \% \text { yield })}{\stackrel{*}{ }}
$$
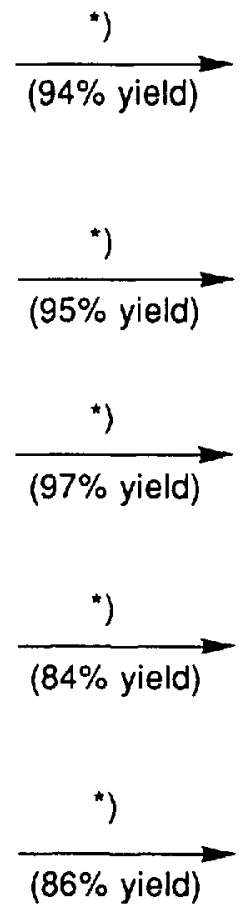

$(86 \%$ yield $)$<smiles>CCOC(=O)C[C@H](C)CCC=C(C)C</smiles>

$(+)-17$<smiles>CCOC(=O)C[C@H](C)CCC=C(C)C</smiles>

$(-)-17$<smiles>CCOC(=O)C[C@@H](C)c1ccccc1</smiles>

(+) -18<smiles>CCOC(=O)C[C@H](C)c1ccccc1</smiles>

$(-)-18$<smiles>CCOC(=O)C[C@@H](C)C(C)C</smiles><smiles>CCOC(=O)C[C@@H](C)C(C)C</smiles>

$(+)-19$

*) Reaction conditions: see Scheme 11 .

Scheme 13<smiles>CNC(=O)/C=C(\C)CCc1ccccc1</smiles>

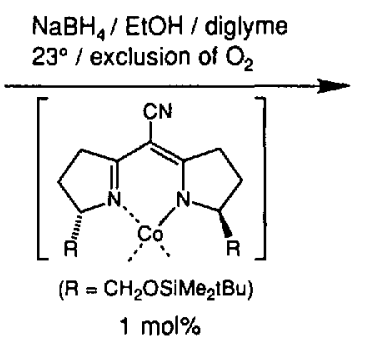<smiles>CNC(=O)CC(C)CCc1ccccc1</smiles>
$1 \mathrm{~mol} \%$

are selectively reduced at the conjugated $\mathrm{C}=\mathrm{C}$ bond, whereas the isolated double bond remains intact.

The corresponding reactions of $\alpha, \beta$-unsaturated carboxamides were found to be much slower and, even at elevated temperature, did not go to completion. However, it has been recently discovered that replacement of DMF by diglyme (di-(2methoxyethyl)ether), leads to a substantial rate enhancement [53]. The reduction of the ester 7 in $\mathrm{EtOH} /$ diglyme $(1: 1)$ is completed within $2 \mathrm{~h}$ as opposed to 2 days in EtOH/DMF (Scheme 1I), whereas the enantioselectivity remains almost the same ( $92 \%$ ee). Under these conditions, the less reactive amides can also be quantitatively reduced. Reduction of the methylamide 20 requires $14 \mathrm{~h}$ and provides the saturated amide $\mathbf{2 1}$ in high yield and with cxcellent enantioselectivity (Scheme 13).

A tentative model, rationalizing the stereoselectivity of (semicorrinato)cobalt catalysts, is proposed in Fig. 6 [41]. In analogy to (corrinato)Co complexes such as vitamin $B_{12}[3 d-f]$, we presume that under the reaction conditions the precatalyst, prepared in situ from $\mathrm{CoCl}_{2}$, is first reduced to a (semicorrinato) $\mathrm{Co}(\mathrm{I})$ complex. The $\mathrm{Co}$ (I) complex then initiates the catalytic cycle by attacking the electrophilic $\mathrm{C}=\mathrm{C}$ bond of the substrate, forming a $\pi$-complex [54] [55] or an alkyl-Co(III) complex [54] with the metal center attached to the $\beta$-C-atom of the substrate. From labeling experiments using $\mathrm{NaBD}_{4}$ in $\mathrm{EtOH} / \mathrm{DMF}$ or $\mathrm{NaBH}_{4}$ in EtOD/DMF, we know that the $\mathrm{H}$-atom introduced into the $\beta$-position stems from borohydride, whereas the $\alpha-\mathrm{H}$ atom comes from EtOH [56]. These findings may be interpreted as follows: $\mathrm{NaBH}_{4}$ transfers a hydride to the Co center of the catalyst-substrate complex (either a Coolefin or a Co-alkyl complex). Intramolecular $\mathrm{H}$-shift from $\mathrm{Co}$ to the $\beta$-C-atom of the substrate then leads to a Co-enolate which is eventually protonated by the solvent. Such a mechanism would imply that the $\beta-\mathrm{H}$-atom is added to the same side of the $\mathrm{C}=\mathrm{C}$ bond which is bound to the catalyst.

If we suppose that the transition state of the enantioselectivity-determining step is similar to the hypothetical $\pi$-complex shown in Fig. 6, the stereoselectivity of the catalyst may be rationalized in the following way: of the two transition structures $\mathbf{A}$ and $\mathbf{B}$ leading to opposite enantiomers, $\mathbf{B}$ is expected to be less favorable because of the steric repulsion between the ester group and the adjacent substituent of the semicorrin ligand. Therefore, the reaction should prefer a pathway via $\mathbf{A}$, in accordance with the experimental findings. The model also explains why the $(E)$-isomers 13 and 15 lead to somewhat higher enantiomeric excesses than the corresponding $(Z)$-isomers 14 and 16 (Scheme I2). Steric interactions of the $\mathrm{Ph}$ or $\mathrm{i}-\mathrm{Pr}$ groups with the semicorrin ligand suggest the type-A transition structures derived from the $(Z)$ isomers to be destabilized (Fig. $6 ; \mathrm{R}^{\prime}=\mathrm{Ph}$ or $\mathrm{i}-\mathrm{Pr}, \mathrm{R}^{2}=\mathrm{Me}$ ) relative to the analogous transition structures derived from the $(E)$ isomers, in which the sterically more encumbered site of the coordination sphere is occupied by the smaller Me group (Fig. 6; $\mathrm{R}^{1}=\mathrm{Me}, \mathrm{R}^{2}=\mathrm{Ph}$ or $\mathrm{i}-\mathrm{Pr}$ ).

The remarkable enantioselectivities which have been observed in the (semicorrinato)Cu-catalyzed cyclopropanation of olefins and in the (semicorrinato)Co-cata- 


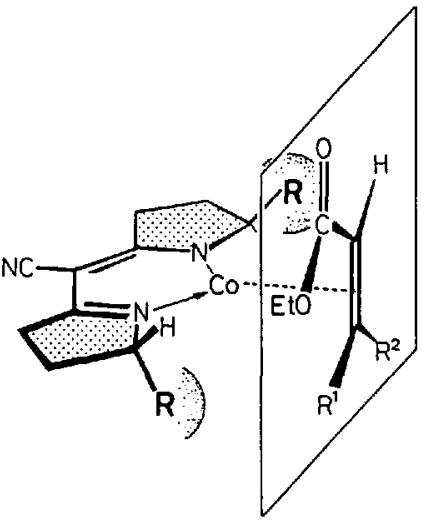

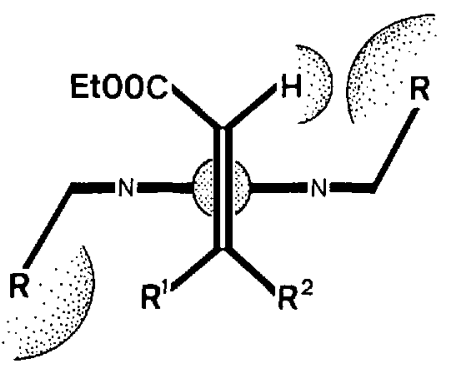

A

Fig. 6. Schematic representation of possible transition states in the (semicorrinato) Co-catalyzed reduction of $\alpha, \beta$-unsaturated carboxylates

lyzed conjugate reduction of $\alpha, \beta$-unsaturated carboxylates and carboxamides point to a considerable potential of semicorrin ligands in enantioselective catalysis. Both cyclopropane formation and conjugate reduction are widely used processes in organic synthesis. However, the scope of semicorrin ligands should by no means be limited to these two classes of transformations. The particular structural features of the semicorrins, the ready access to these compounds, and the ease of modifying their structures offer ideal opportunities for designing new catalyst systems for different applications in a rather straightforward, rational manner.

\section{Conclusion}

One of the aims of this article was to show that metal-catalyzed reactions can be effectively controlled by organic ligands and that the design, and synthesis of suitable ligands for this purpose can be a challenging task for organic chemists. Although in terms of efficiency and selectivity synthetic metal complexes cannot yet compete with biological catalysts which have evolved to perfection over billions of years, they have already proved to be highly valuable tools in organic synthesis. Considering the wealth of organic reactions that can be catalyzed by metals and the unlimited possibilities of combining a catalytically active metal with various types of organic ligands, there is no doubt that the development of this field is still in

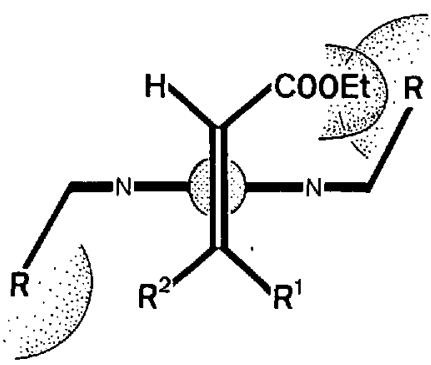

B
[1] J.P. Collman, L. S. Hegedus, J. R. Norton, R. G. Finke, 'Principles and Applications of Organotransition Metal Chemistry', University Science Books, Mill Valley, CA, 1987; S.G. Davies, 'Organotransitionmetal Chemistry: Applications to Organic Synthesis', Pergamon, Oxford, 1982. H. Werner, G. Erker, Eds., 'Organometallics in Organic Synthesis', Springer, Berlin-Heidelberg, 1988/89, Vols. 1 and 2

[2] S. Otsuka, T. Yamanaka, Eds., 'Metalloproteins', 'Bioactive Molecules', Kodansa-Elsevier, TokyoAmsterdam, 1988, Vol.8; A.V. Xavier, Ed., 'Frontiers in Bioinorganic Chemistry', VCH Verlagsgesellschaft, Weinheim, 1986; R.J.P. Williams, "Metalloenzyme Catalysis: The Entatic State', J. Mol. Catal., Review Issue 1986, I.

[3] a) B. Kräutler, 'The Porphinoids - Versatile Biological Catalyst Molecules', Chimia 1987, 41, 277; b) D. Dolphin, Ed., 'The Porphyrins', Academic Press, New York, 1978/79, Vols. I-VII; c) K. M. Smith, Ed., 'Porphyrins and Metalloporphyrins', Elsevier, Amsterdam, 1975; d) B. Kräutler, 'Vita$\min B_{12}$ (und natürliche Corrinoide)', in 'Vitamine II', Eds. O. Isler, G. Brubacher, S. Ghisla, and B. Kräutler, Thieme, Stuttgart-New York, 1988, pp. 340-388; e) Z. Schneider, A. Stroinski, 'Comprehensive $\mathbf{B}_{12}$, W. de Gruyter, Berlin-New York, 1987 ; ) D. Dolphin, Ed., 'B ${ }_{12}$ ', Wiley, New York, 1982, Vols. 1 and 2.

[4] R.P. Gunsalus, R.S. Wolfe, FEMS Microbiol. Letl. 1978, 3, 191.

[5] Unpublished observation by J. LeGall (University of Georgia) reported in: R.S. Wolfe, Trends Biochem. Sci. 1985, 10, 396.

[6] a) G. Diekert, B. Klee, R. K. Thauer, Arch. Microbiol. 1980, 124, 103; b) W.B. Whitman, R.S. Wolfe, Biochem. Biophys. Res. Conmun. 1980,92, 1196.

[7] a) R. Cammack, 'Nickel in Metalloproteins', $A d v$. Inorg. Chem. 1988, 32, 297; b) J. R. Lancaster, Jr., Ed., 'The Bioinorganic Chemistry of Nickel', VCH Publishers, New York, 1988; c) C. T. Walsh, W. H. Orme-Johnson, 'Nickel Enzymes', Biochemistry 1987, 26, 4901; d) R. K. Thauer, 'Nickelenzyme im Stoffwechsel von methanogenen Bakterien', Biol. Chem. Hoppe-Seyler 1985, $366,103$.

[8] Recently, another porphinoid Ni complex named 'tunichlorin' has been isolated form the Caribbean tunicate Trididemnum solidum: K.C. Bible, M. Buytendorp, P.D. Zierath, K. N. Rinehart, Proc. Natl. Acad. Sci. U.S. A. 1988, $85,4582$.

I would like to express my sincere gratitude to Prof. Albert Eschenmoser; his continuous support and encouragement provided the basis for the work described herein. The results presented in the chapter on coenzyme $F 430$ originate from a longstanding collaboration between the research groups of Prof. Rudolf $K$. Thauer at the University of Marburg and Prof. A. Eschenmoser at the ETH Zürich. The numerous contributions of their coworkers, among them Dorothe Ankel-Fuchs, Gabriele Diekert, Hans Harald Gilles, Rudolf Hüster, Rolf Jaenchen, Johanna Moll (University of Marburg), and Dr. Douglas A. Livingston, Alex Fässler, and Dr. Jakob Schreiber (ETH) are gratefully acknowledged. I owe special thanks to my colleague Dr. Bernhard Jaun (ETH Zürich) for the fruitful collaboration in the F430 project. His experimental and intellectual contributions were essential to this work. Most of the experiments described in the chapter on enantioselective catalysis were carried out by Hugo Fritschi. Urs Leutenegger, and Carmen Piqué, to whom I express my gratiude for their enthusiasm and perseverance. I also thank Konstantin Siegmann, Andrew Madin, Thomas Koch, Rudolf Eugster, and Peter von Matt who contributed many important results during the three months of their 'Diplomarbeit'. Financial support by the Swiss National Science Foundation, F. HoffmannLa Roche $A G$, Basel, and the ETH-Zürich is gratefully acknowledged.
[9] a) G. Diekert, R. Jaenchen, R. K. Thauer, FEBS Lett. 1980, 119, 118; b) R. Jaenchen, G. Diekert, R. K. Thauer, ibid. 1981, 130, 133.

[10] a) A. Pfaltz, B. Jaun, A. Fässler, A. Eschenmoser, R. Jaenchen, H.H. Gilles, G. Diekert, R. K. Thauer, Helv. Chim. Acta 1982, 65, 828; b) D. A. Livingston, A. Pfaltz, J. Schreiber, A. Eschen. moser, D. Ankel-Fuchs, J. Moll, R, Jaenchen, R.K. Thauer, ibid. 1984, 67, 334; c) A. Pfaltz, D.A. Livingston, B. Jaun, G. Diekert, R. K. Thauer, A. Eschenmoser, ibid. 1985, 68, 1338; d) A. Fässler, A. Kobelt, A. Pfaltz, A. Eschenmoser. C. Bladon, A.R. Battersby, R.K. Thauer, ibid. $1985,68,2287$

[11] A. Pfaltz, 'Structure and Properties of Coenzyme F430', in [7b], pp. 275-298.

[12] A. R. Battersby, E. McDonald, in [3c], pp. 61-116; A. I. Scott, Pure Appl. Chem. 1981, 53,1215

(13] A. Fässler, A. Pfaltz, P. M. Müller, S. Farooq, Ch. Kratky, B. Kräutler, A. Eschenmoser, Helv. Chim. Acta 1982, 65, 812 .

[14] Ch. Kratky, W. Keller, A. Kobelt, Ch. Spinner, B. Jaun, A. Pfaltz, A. Eschenmoser, unpublished results.

[15] W. L. Ellefson, W. B. Whitman, R.S. Wolfe, Proc. Natl. Acad Sci. U.S. A. 1982, 79, 3707

[16] R.P. Hausinger, W. H. Orme-Johnson, C. Walsh, Biochemistry 1984, 23, 801

[17] A. Eschenmoser, 'Chemistry of Corphinoids', Ann. N. Y. Acad. Sci. 1986, $47 I, 108$.

[18] G. Schlingmann, B. Dresow, L. Ernst, V. B. Koppenhagen, Liebigs Ann. Chem. 1981, 2061; G. Schlingmann, B. Dresow, V. B. Koppenhagen, W. 
Becker, W.S. Sheldrick, Angew. Chem. 1980, 92, 304; ibid. Int. Ed. 1980, 19, 321; A. Gossauer, B. Grüning, L. Crust, W. Becker, W.S. Sheldrick, Angew. Chem. 1977, 89, 486; ibid. Int. Ed. 1977, 16,481 .

[19] Ch. Kratky, R. Waditschatka, Ch. Angst, J.E Johansen, J.C. Plaquevent, J. Schreiber, A Eschenmoser, Helv. Chim. Acta 1985, 68, 1312.

[20] a) A. Fässler, A. Pfaltz, B. Kräutler, A. Eschenmoser, J. Chem. Soc., Chem. Commun. 1984, 1365 b) Ch. Kratky, A. Fässler, A. Pfaltz, B. Kräutler, B. Jaun, A. Eschenmoser, ibid. 1984, 1368

[21] A. K. Shiemke, W. A. Kaplan, C. L. Hamilton, J.A. Shelnutt, R. A. Scott, J. Biol. Chem. 1989 264. 7276; A. K. Shiemke, J.A. Shelnutt, R.A Scott, ibid. 1989, 264, 11236; C. Hamilton, R. A Scott, M. K. Johnson, ibid. 1989, 264, 11605

[22] Increasing electrophilicity at the metal center as a consequence of expanding the ring size of the macrocycle is a general phenomenon in macrocyclic metal complexes which has been well documented in other systems by Bush: D. H. Bush, $A c c$ Chem. Res. 1978, 11, 392; F. V. Lovecchio, E.S Gore, D. H. Bush, J. Am. Chem. Soc. 1974, 96. 3109.

[23] a) P.E. Rouvière, R.S. Wolfe, 'Novel Biochem istry of Methanogenesis', J. Biol. Chem. 1988, 263 . 7913 ; b) R.P. Hausinger, 'Nickel Utilization by Microorganisms', Microbiol. Rev. 1987, 51, 22; $c f$. also ref. [7c]

[24] a) W. L. Ellefson, R. S. Wolfe, J. Biol. Chem. 1980, 255, 8388; ibid. 1981, 256, 4259; b) J. Ellermann, S. Rospert, R.K. Thauer, M. Bokranz, A. Klein, M. Voges, A. Berkessel, Eur. J. Biochem. 1989 184, 63; c) L.P. Wackett, J. F. Honek, T.H. Begley, S.L. Shames, E.C. Niederhoffer, R.P. Hausinger, W.H. Orme-Johnson, C.T. Walsh, 'Methyl-S-Coenzyme-M Reductase: A NickelDependent Enzyme Catalyzing the Termina Redox Step in Methane Biosynthesis', in [7b] pp. 249-274.

[25] K. M. Noll, K. L. Rinehart, Jr., R. S. Tanner, R.S Wolfe, Proc. Natl. Acad. Sci. U.S.A. 1986, 83 4238; K. M. Noll, M.I. Donelly, R. S. Wolfe, $J$ Biol. Chem. 1987, 262, 513; A. Kobelt, A. Pfaltz, D. Ankel-Fuchs, R. K. Thauer, FEBS Lett. 1987, 214, 265.

[26] T. A. Bobik, K. D. Olson, K.M. Noll, R. S. Wolfe, Biochem. Biophys. Res. Commun. 1987, 149, 455 J. Ellermann, R. Hedderich, R. Böcher, R.K. Thauer, Eur. J. Biochem. 1988, 172, 669

[27] R. Hedderich, R. K. Thauer, FEBS Lett. 1988 234, 223; R. Hedderich, A. Berkessel, R.K. Thauer, ibid. 1989, 255, 67.

[28] B. Jaun, A. Pfaltz, J. Chem. Soc., Chem. Commun. 1986, 1327.

[29] B. Jaun, 'Redox Chemistry of Coenzyme F430, the Hydrocorphinoid Nickel Complex Catalysing Methane Formation in Methanogenic Bacteria', in 'The Biological Alkylation of Heavy Elements', Eds. P. J. Craig and F. Glockling, Special Publ. No.66, The Royal Society of Chemistry, London, 1988, pp. 20-30.

[30] D. Lexa, J. M. Savéant, Acc. Chem. Res. 1983, I6, 235.

[31] For studies on the reduction of other nickel porphinoids, see, e.g.: L. R. Furenlid, M.W. Renner K.M. Smith, J. Fajer, J. Am. Chem. Soc. 1990 112, 1634; A.M. Stolzenberg, M. T. Stershic, ibid. 1988, 110,6391 ; D. Lexa, M. Momenteau, J. Mispelter, J.M. Savéant, Inorg. Chem. 1989, 28, 30 K. M. Kadish, D. Sazou, G. B. Maiya, B.C. Han Y. M. Liu, A. Saoiabi, M. Ferhat, R. Guilard, ibid. 1989, 28, 2542

[32] S.P.J. Albracht, D. Ankel-Fuchs, R. Böcher, J. Ellermann, J. Moll, J.W. van der Zwaan, R.K. Thauer, Biochim. Biophys. Acta 1987, 955, 86.

[33] Such a signal has also been observed by $J . A$
Krzycki and R.C. Prince in active cells of Methanosarcina barkeri during $\mathrm{CH}_{4}$ production from acetate (J.A. Krzycki, Dept. of Microbiology, Ohio State University, Columbus, Ohio, personal communication).

[34] B. Jaun, A. Pfaltz, J. Chem. Soc., Chem. Commun. 1988, 293.

[35] M.J. D'Aniello, E. K. Barefield, J. Am. Chem. Soc. 1976, 98, 1610; A. Bakac, J.H. Espenson ibid. 1986, 108,713

[36] a) J.D. Morrison, Ed., 'Asymmetric Synthesis', 'Chiral Catalysis', Academic Press, Orlando Florida, 1985, Vol. 5; b) B. Bosnich, Ed., 'Asymmetric Catalysis', Martinus Nijhoff, Dordrecht, 1986; c) $\mathrm{H}$. Brunner, 'Enantioselective Synthesis of Organic Compounds with Optically Active Transition Metal Catalysts in Substochiometric Quantities', Topics Stereochem. 1988, 18, 129; Synthesis 1988, 645; d) R. Noyori, M. Kitamura, "Enantioselective Catalysis with Metal Complexes. An Overview', in 'Modern Synthetic Methods 1989', Ed. R. Scheffold, Springer, Berlin-Heidelberg 1989, pp. 115-198.

[37] T. Katsuki, K. B. Sharpless, J. Am. Chem. Soc. 1980, 102, 5974; Y. Gao, R. M. Hanson, J.M. Klunder, S. Y. Ko, H. Masamune, ibid. 1987, 109 5765 ; B. E. Rossiter, 'Synthetic Aspects and Applications of Asymmetric Epoxidation', in [36a] pp. 194-246; M. G. Finn, K. B. Sharpless, 'On the Mechanism of Asymmetric Epoxidation with Titanium-Tartrate Catalysts', in [36a], pp. 247-308

[38] W.S. Knowles, M.J. Sabacky, J. Chem. Soc. Chem. Commun. 1968, 1445; L. Horner, H. Siegel H. Büthe, Angew. Chem. 1968, 80, 1034; ibid. Int Ed. 1968, 7, 942; T. P. Dang, H. Kagan, J. Chem Soc., Chem. Commun. 1971, 481; K.E. König 'The Applicability of Asymmetric Homogeneous Catalytic Hydrogenation', in [36a] pp. 71-101; J Halpern, 'Asymmetric Catalytic Hydrogenation Mechanism and Origin of Enantioselection', in [36a], pp. 41-69.

[39] a) R. Noyori, M. Ohta, Y. Hsiao, M. Kitamura T. Ohta, H. Takaya, J. Am. Chem. Soc. 1986, 108 7117; H. Takaya, T. Ohta, N. Sayo, H. Kumobayashi, S. Akutagawa, S. Inoue, 1. Kasahara R. Noyori, ibid. 1987, 109, 1596; T. Ohta, H Takaya, M. Kitamura, K. Nagai, R. Noyori, Org. Chem. 1987, 52, 3174; M. Kitamura, T. Ohkuma, S. Inoue, N. Sayo, H. Kumobayashi, S Akutagawa, T. Ohta, H. Takaya, R. Noyori, Am. Chem. Soc. 1988, 110, 629; R. Noyori, T Ikeda, T. Ohkuma, M. Widhalm, M. Kitamura H. Takaya, S. Akutagawa, N. Sayo, T. Saito, T. Taketomi, H. Kumobayashi, ibid. 1989, III 9134; b) T. Ikariya, Y. Ishii, H. Kawano, T. Arai, M. Saburi, S. Yoshikawa, S. Akutagawa, J. Chem Soc., Chem. Commun. 1985, 922; H. Kawano, Y Ishii, T. Ikariya, M. Saburi, S. Yoshikawa, Y. Uchida, H. Kumobayashi, Tetrahedron Let 1987, 28, 1905; M. Saburi, Y. Uchida, H Kawano, Y. Ishii, M. Saburi, Y. Uchida, J. Chem Soc., Chem. Commun. 1988, 87

[40] The name 'semicorrin' was originally proposed by Stevens [44]. Systematic name of the parent ligand system: 3,4-dihydro-5-[(pyrrolidin-2-ylidene) methyl]-2H-pyrrole.

[41] A. Pfaltz, 'Enantioselective Catalysis with Chira Cobalt and Copper Complexes', in 'Modern Synthetic Methods 1989', Ed. R. Scheffold, Springer, Berlin-Heidelberg, 1989, pp. 199-248.

[42] There are numerous cases, documenting the advantages of $C_{2}$-symmetric reagents, catalysts, or ligands in asymmetric synthesis. See, e.g.: J.K. Whitesell, ' $C_{2}$ Symmetry and Asymmetric Induction', Chem. Rev. 1989, 89, 1581.

[43] E. Bertele, H. Boos, J.D. Dunitz, F. Elsinger, A Eschenmoser, I. Felner, H.P. Gribi, H Gschwend, E. F. Meyer, M. Pesaro, R. Scheffold
Angew. Chem. 1964, 76, 393; ibid. Int. Ed. 1964, 3 490 ; W. Häusermann, 'Untersuchungen über Iminoesterkondensationen im Zusammenhang mi dem Aufbau des Corrinsystems', Dissertation ETH-Zürich Nr. 3754, 1966; b) Y. Yamada, D Miljkovic, P. Wehrli, B. Golding, P. Löliger, R Keese, K. Müller, A Eschenmoser, Angew Chem. 1969, 8I, 301; ibid. Int. Ed. 1969, 8, 343; M. Roth P. Dubs, E. Götschi, A. Eschenmoser, Helv. Chim Acta 1971, 54, 710; E. Götschi, W. Hunkeler, H. J.

Wild, P. Schneider, W. Fuhrer, J. Gleason, A. Eschenmoser, Angew. Chem. 1973, 85, 950; ibid. Int. Ed. 1973, 12, 910; A. Eschenmoser, Quart. Rev. Chem. Soc. 1970, 24, 366; A. Eschenmoser, C. E. Wintner, Science 1977, 196, 1410; N. Bühler, A. Eschenmoser, published in: N. Bühler 'Syn' thetische und mechanistische Studien zum Aufbau corrinoider Metallkomplexe durch lichtinduzierte A/D-Cycloisomerisierung', Dissertation, ETH. Zürich Nr.5154, 1973; A Pfaltz N. Bühler, R Nejer, K. Hirai, A. Eschenmoser, Helv. Chim. Acta 1977, 60, 2653

[44] R. V. Stevens, L. E. DuPree, Jr., M.P. Wendtland, J. Chem. Soc. Chem. Commun. 1970, 821; R. V. Stevens, Tetrahedron 1976, 32, 1599.

[45] H. Fritschi, U. Leutenegger, K. Siegmann, A. Pfaltz, W. Keller, Ch. Kratky, Helv. Chim. Acta $1988,71,1541$

[46] U. Leutenegger, 'Enantioselektive Katalyse mit Semicorrin-Ubergangsmetallkomplexen', Dissertation, ETH-Zürich Nr. 9091, 1990.

[47] A.P. Johnson, P. Wehrli, R. Fletcher, A. Eschenmoser, Angew. Chem. 1968, 80, 622; ibid. Int. Ed. 1968, 7, 623; P. Wehrli, 'Versuche zur Synthese von Corrin-Komplexen', Dissertation, ETHZürich Nr. 4043, 1967; R. Neier, A. Eschenmoser, published in: $R$. Neier 'Uber den Mechanismus der photochemischen A/D-Secocorrin $\rightarrow$ CorrinCycloisomerisierung', Dissertation, ETH-Zürich Nr.6178, 1978.

[48] H. Fritschi, 'Chirale Kupfer-Semicorrin-Komplexe als enantioselektive Katalysatoren für die Cyclopropanierung von Olefinen'. Dissertation ETH-Zürich Nr.8951, 1989.

[49] a) H. Fritschi, U. Leutenegger, A. Pfaltz, Angew. Chem. 1986, 98, 1028; ibid. Int. Ed. 1986, 25, 1005 b) H. Fritschi, U. Leutenegger, A. Pfaltz, Helv Chim. Acta 1988, 7I, 1553.

[50] H. Nozaki, H. Takaya, S Moriuti, R. Noyori, Tetrahedron 1968, 24, 3655; T Aratani, Y Yoneyoshi, T. Nagase, Tetrahedron Lett. 1975 1707; ibid. 1977, 2599; ibid. 1982, 23, 685; T Aratani, Pure Appl. Chem. 1985, 57, 1839.

[51] Y Tatsuno, A. Konishi, A. Nakamura, S Otsuka, I. Chem. Soc. Chem. Commun. 1974, 588; A. Nakamura, A. Konishi, Y. Tatsuno, S. Otsuka, J Am. Chem. Soc. 1978, 100, 3443; A. Nakamura A. Konishi, R. Tsujitani, M. Kudo, S. Otsuka ibid. 1978, 100, 3449; A. Nakamura, Pure Appl. Chem. 1978, 50, 37

[52] U. Leutenegger, A. Madin, A. Pfaltz, Angew Chem. 1989, 101, 61; ibid. Int. Ed. 1989, 28, 60 .

[53] A. Pfaltz, R. Eugster, P. von Matt, unpublished results.

[54] G. N. Schrauzer, J.H. Weber, T. M. Beckham, $J$ Am. Chem. Soc. 1970, 92, 7078; G. N. Schrauzer Acc. Chem. Res. 1968, 1, 97.

[55] See e. . D Dodd M.D Johnson, J Organomet. Chem. 1973, 52, 1; T. Funabiki, J. Chem. Soc. Chem. Commun. 1979, 1116

[56] A. Pfaltz, T. Koch, unpublished results; $c f$. [46].

[57] P. van Beelen, A. P. M. Stassen, J.W. G. Bosch G.D. Vogels, W. Guijt, C. A. G. Haasnot, Eur. J. Biochem. 1984, 138, 563; J.C. Escalante-Semerena, J. A. Leigh, K. L. Rinehart, Jr., R.S. Wolfe Proc. Natl. Acad. Sci. U.S. A. 1984, 81, 1976. 